NSF. IDOE

\title{
EFFECTS OF POLLUTANTS ON MARINE ORGANISMS
}

\section{intw}
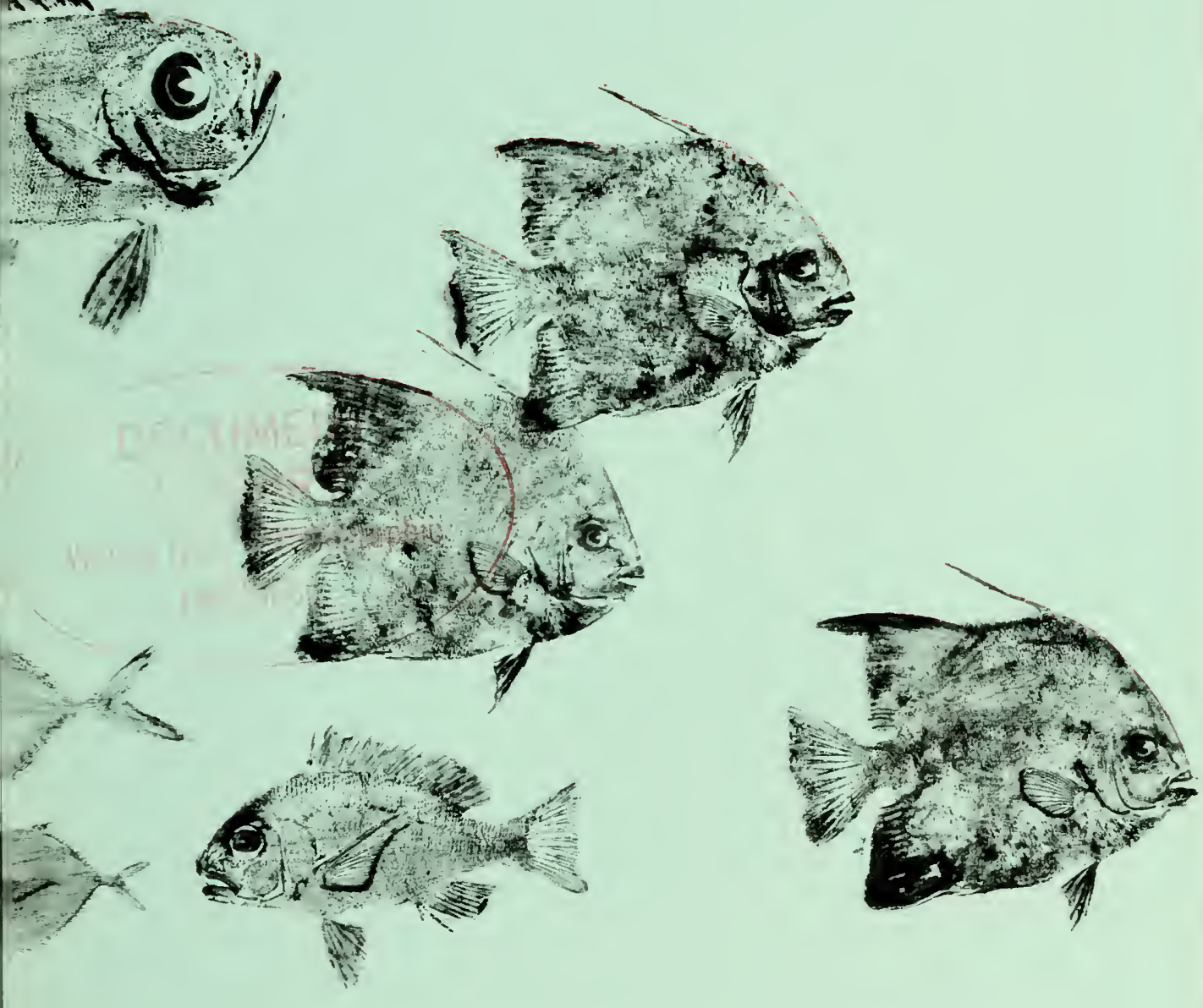

QP

3,2

$\mathrm{PH}$

Deliberations and Recommendations of the

害 National Science Foundation,

E4 International Decade of Ocean Exploration Effects of Pollutants on Marine Organisms Study August 11-14, 1974 


\section{Given in Loving Memory of}

\section{Raymond Braislin Montgomery}

Scientist, $R / V$ Atlantis maiden voyage

$2 \mathrm{Jul} / \mathrm{V}-26$ August, 1931 ********

Woods Hole Oceanographic Institution Physical Oceanographer 1940-1949

Non-Resident Staff 1950-1960

Visiting Committee 1962-1963

Corporation Member

$1970-1980$

$* * * * * *$

Faculty, New York University 1940-1944

Faculty, Brown University 1949-1954

Faculty, Johns Hopkins University

1954-1961

Professor of Oceanography, Johns Hopkins University 1961-1975 
NSF.IDOE

1974

$E 33$

\section{Effects of Pollutants}

\section{on}

Marine Organisms

Deliberations and Recommendations of the NSF/IDOE Effects of Pollutants on Marine

Organisms Workshop held in Sidney, British Columbia, Canada

August 11-14, 1974

Patrick L. Parker, convener and editor

University of Texas

Marine Science Institute

Port Aransas, Texas

David Menzel, host and co-convener

University of Georgia

Skidaway Institute of Oceanography

Savannah, Georgia
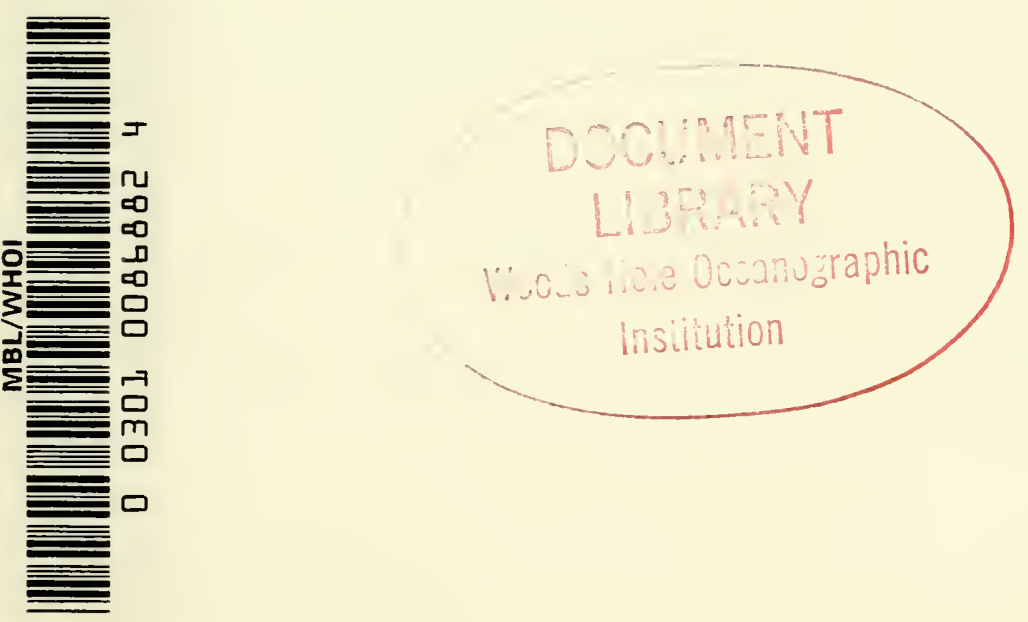
Any opinions, findings, conclusions, or recommendations expressed herein are those of the authors and do not necessarily reflect the views of the National Science Foundation. 


\section{Contents}

Foreword . . . . . . . . . . . . . . . 5

Preface . . . . . . . . . . . 7

Introduction and Recommendations . . . . . . . . 9

General Recommendations

Specific Recommendations

Program Accomplishments . . . . . . . . . 11

Biological Effects: Microalgae and Bacteria . . . . . 12

Low Molecular Weight Hydrocarbons (LMWHC)

Spatial and Temporal Distribution of LMWHC in

the Gulf of Mexico

Heavy Petroleum Hydrocarbons

Hydrocarbon Solubility

Phthalate Esters

Biological Effects: Marine Animals . . . . . . . 26

Heavy Hydrocarbons

Trace Metals

Polychlorinated Biphenyl (PCB)

Phthalate Esters

Conclusion . . . . . . . . . . . . . 40

References . . . . . . . . . . . . . 41

Appendices . . . . . . . . . . . . 42

1. NSF/Effects of Pollutants on Marine

Organisms Program Executive Committee

2. IDOE Projects for Effects of Pollutants on Marine Organisms Program

3. Publications Resulting from the NSF/IDOE Effects of Pollutants on Marine Organisms Program

4. NSF/IDOE Effects of Pollutants on Marine Organisms Program Workshop Participants, Sidney, B.C., Canada, August 11-14, 1974 



\section{Foreword}

"Preserve the ocean environment by accelerating scientific observations of the natural state of the ocean and its interactions with the coastal margin-to provide a basis for (a.) assessing and predicting man-induced and natural modifications of the character of the oceans; (b.) identifying damaging or irreversible effects of waste disposal at sea; and (c.) comprehending the interaction of various levels of marine life to permit steps to prevent depletion or extinction of valuable species as a result of man's activities."

The above is the first of the six prescribed goals of the National Science Foundation's Office for the International Decade of Ocean Exploration. In pursuit of this goal, IDOE, in 1971, carried out a oneyear Baseline Data Acquisition Program and in the following year initiated the Pollutant Transfer Program. The Baseline Program indicated the present levels of contamination by trace metals and petroleum and chlorinated hydrocarbons in water, sediment and biota of the oceans. The Pollutant Transfer Program provides information on the pathways or mechanisms controlling the rate of pollutant transfer from the source to and within the ocean, the information so necessary for predicting the distribution of pollutants, for assessing whether the oceans are becoming measurably polluted, and ultimately for indicating rates at which pollutants may be released safely to the environment.

The IDOE Effects of Pollutants on Marine Organisms Program is designed to learn whether the levels of pollutants shown to be present in the oceans in the Baseline and Transfer Programs are now having or may in the future have a deleterious effect on life in the sea. Such potential damage is the overriding reason for studies of ocean pollution.

The goals of the research projects in the Effects of Pollutants on Marine Organisms Program were established as: (1.) to establish the level of pollutant just necessary to cause clear mortality for open ocean and coastal marine organisms; (2.) to determine the sublethal effects of pollutants on organisms; (3.) to learn the mechanism of pollutant effect on specific critical functions; (4.) to identify by careful chemical analyses the toxic or damaging chemical species.

To attain these ends, a broad based program was designed around a matrix consisting of the pollutants of concern (trace metals, chlorinated hydrocarbons and petroleum and its products) and the various levels of marine organisms from bacteria to fish. The Program design 
also took into account the fact that the IDOE Controlled Ecosystem Pollution Program was focusing on the effects of trace metals on planktonic communities. This report is an assessment of the first twoyear (1973-75) effort of the investigators of the Effects Program.

The publication of this volume has resulted from the dedicated efforts of the staff of IDOE including (visiting) Program Managers, Dr. George Grice, Woods Hole Oceanographic Institution; Dr. Patrick L. Parker, University of Texas, Marine Science Institute; Dr. C. S. Giam and Dr. B. J. Presley, both of Texas A \& M University, and Program Secretary, Ms. S. Robinson. I am grateful to the conveners, participants and special guests who participated in the meeting in Sidney, British Columbia, especially the IDOE grantees whose data resulted in the publication of this report. I would also like to thank Drs. Tim Parsons and Dave Menzel for the hospitality extended to the group at Sidney.

Invaluable editorial assistance was rendered by Ms. Ruth Grundy and Ms. Geraldine Ard. Cover and symbol were created by Ms. Dinah Bowman.

Feenan D. Jennings, Head Office for the International Decade of Ocean Exploration 


\section{Preface}

The scientific results of a two-year research program, Effects of Pollutants on Marine Organisms Program, is described in this volume. This Program is a part of the Environmental Quality Program of the National Science Foundation, Office for the International Decade of Ocean Exploration. The volume summarizes the deliberations of a workshop meeting of the Program participants and invited scientists which was held in Sidney. British Columbia, Canada, on August 11-14. 1974. Due to time and space limitations the extensive data presented by the participants is not given here. The reader may write participants for publications or copies of the detailed preworkshop paper which each investigator contributed to the workshop.

Research in the Effects Program has focused on determining sublethal effects of low levels of chemical pollutants on bacteria, microalgae and animals. The chemical pollutants studied were petroleum, trace metals. chlorinated hydrocarbon and phthalates. In the case of petroleum, a highly complex mixture, research has been done to isolate and identify toxic components. Selection and laboratory culture of appropriate marine organisms has been a major initial research task. In addition to selecting appropriate physiological parameters by which to measure biological effects, research was begun to discover the mechanism of pollutant damage for selected organisms. During the two years of this Program the investigators have made progress in all of these areas so that well documented facts are becoming available.

The community of marine scientists has been called upon by society to answer the very complex question of the effects of pollutants on life in the sea when the state of our knowledge does not really answer the question as to how life functions under normal conditions. The support provided by NSF/IDOE has allowed these scientists to address the fundamental aspects of this important applied problem. The Workshop was organized into two working groups. Jack Anderson was chairman of the group dealing with animals and Chase Van Baalen of the group concerned with plants and bacteria.

We thank Dave Menzel, Tim Parsons and the resident staff of the Controlled Ecosystem Pollution Experiment (CEPEX) for serving as host for the Sidney Workshop. Dave and the staff at the Skidaway Institute of Oceanography get special thanks for putting together the preconference workshop volume. Martena Baker's work during the Workshop earned everyone's gratitude.

Patrick L. Parker 



\section{Introduction and Recommendations}

The principal reason for concern about the presence of chemical pollutants in the marine environment is the possibility that marine life will be adversely affected. The objectives of the Effects of Pollutants on Marine Organisms Program of the National Science Foundation, Office for the International Decade of Ocean Exploration are to measure the effects of chemical pollutants on individual marine organisms and to assess the significance of the data for the ocean. The inadequacy of acute toxicity tests and the conceptual framework for more comprehensive research are given in Marine Environmental Quality (NAS. 1971). The NSF/IDOE Baseline Studies Conference (1972), concluded that there is readily identifiable contamination of the open ocean and recommended that the highest priorities be given to determining the impact of pollutants on marine life.

The Program accomplishments summarized in the following pages are presented in two sections: Effects on bacteria and microalgae, and on animals. Supporting chemical investigations are included in each of the two sections.

During the Workshop the participants tried to assess the significance of the reported biological effects. In so doing it was recognized that some of these early results were significant and should be followed up but at the same time it was noted that important problems were not being investigated. These observations are reflected in the recommendations for future research and environmental management section of this report.

\section{General Recommendations}

1. The participants recommended that the Effects Program have more formal internal coordination and management. To this end the investigators established an Executive Committee for the Program and charged it with; program formulation, communication among investigators, coordination, supplying chemical pollutants from a common source to all investigators, stimulating intercalibration and standard experiments, and identifying research topics not being adequately covered.

2. The participants recommend that the Effects Program be more closely coordinated with other IDOE Environmental Quality Pro- 
grams, in particular the Pollutant Transfer Program and the Controlled Ecosystem Pollution Experiment (CEPEX). CEPEX was felt to be the other half of an overall effects program. The Executive Committees of the Programs could arrange for data exchange and joint planning.

3. The participants recommend that a field experiment be carried out on shipboard in order to utilize some of the non-lethal biological tests developed by the Effects Program. Such a joint experiment might also involve Transfer and CEPEX investigators.

\section{Specific Recommendations}

1. It was recommended that biological effects studies on biota from the continental shelf and open sea be continued. Such studies should go beyond lethal dose experiments to sub-lethal effects. The mechanisms for both killing and sub-lethal biological effects are poorly understood and require further study.

2. It was recommended that representative species of organisms from the following groups be studied:

(a) phytoplankton of the open ocean and coastal areas

(b) fish of the continental shelf

(c) marine crustacea, with special focus on crab, shrimp, amphipods and mysids

(d) mollusks

(e) echinoderms

3. For comparison of relative sensitivity toward pollution it was recommended that similar but less extensive studies be done on estuarine organisms.

4. It was recommended that increased effort be directed at two difficult technical problems which have emerged from the Program (i) the cultivation in the laboratory of open ocean marine plants and animals (ii) the development of improved physiological and biochemical parameters for detecting biological effects.

5. It was recognized that the Effects Program is highly biological in nature and should remain so but it was recommended that strong chemical projects be carried out in support of the biology especially with regard to characterizing petroleum toxins.

6. It was recommended that geochemical transport, accumulation and retention studies be done for selected pollutants. Such studies should be related to the IDOE Pollutant Transfer Program. 


\section{Program Accomplishments}

The biological effects research program was undertaken with the knowledge that the concentrations of chemical pollutants (petroleum, trace metals and chlorinated hydrocarbons) in coastal seas, and in some cases the open sea, are high enough to be readily detected. (Baseline Studies, 1972; Pollutant Transfer. 1974; Marine Pollution Monitoring, 1972). This knowledge lent urgency to the question of potential biological damage by these levels of pollutants. Although at first this may seem to be a completely biological problem it is in fact more complex. All the investigators have followed three guidelines in their studies: (1) a strong analytical chemistry component was present to insure that the concentration and chemical identity of the pollutants being studied were measured; (2) the levels of pollutants used in biological effects experiments were those known to occur in the marine environment or to be potentially obtainable; (3) the investigators made a sustained effort to develop measures of biological effect other than the lethal dose. This work was made difficult by the fact that many of the more significant marine organisms were not generally in laboratory culture. A good deal of work during these two years has gone into learning to rear organisms and to develop appropriate nonlethal parameters of biological effects.

The investigators focused much of their effort on petroleum, partially because the CEPEX investigators are focusing their effort on heavy metals. In order to insure that experiments could be compared the investigators generally used identical petroleum samples. The American Petroleum Institute standard oils were obtained by the Texas A\&M group and made available to all Program Participants. 


\section{Biological Effects: Microalgae and Bacteria}

The conversion of inorganic to organic carbon by the phytoplankton in the sea represents $60-80 \%$ of the total photosynthesis on earth. The phytoplankters are the food for the zooplankters which in turn are the food of higher organisms and so up through the food web of the marine ecosystems. Thus, any substance which inhibits the growth of primary producers is also limiting the food supply of higher trophic levels with potentially disasterous consequences on the entire marine ecosystem. It is therefore extremely important to determine the effects of various chemical contaminants on phytoplankton in order to be able to make informed predictions and, through governmental restriction of the inputs of certain toxic agents to the ocean, avert serious damage.

\section{Low Molecular-Weight Hydrocarbons}

A group at Texas A\&M University is studying the effects of $\mathrm{C}_{5}$ to $\mathrm{C}_{10}$ aliphatic and aromatic hydrocarbons on the rate of photosynthesis of mixed ocean cultures of phytoplankters at sea and of cultures of the diatom Skeletonema costatum in the laboratory. Carbon fixation rates, using the radiocarbon technique of Stieman-Nielsen, are determined as a function of added pollutant concentrations. A summary of the data is given in Table 1.

One of the most striking aspects of the data in Table 1 is that the aliphatic hydrocarbons depress the photosynthetic rate considerably more than do the aromatic hydrocarbons for a given concentration. This is in contrast to the classical $\mathrm{LD}_{50}$ data which indicate that aromatic hydrocarbons are the most toxic components of petroleum. These data indicate an increased toxicity related to increased substitution on the benzene ring. It was observed that certain concentrations of benzene produced an increase in the uptake of carbon. This apparent stimulation has been observed for long term experiments and no ecological significance is attached to it.

Spatial and Temporal Distribution of LMWHC in the Gulf of Mexico

Dissolved low-molecular-weight hydrocarbon concentrations in surface water have been determined for several thousand miles of cruise tracks of the Texas A\&M University ships, R/V Alaminos and R/V Gyre. in the Gulf of Mexico on each of the five short cruises made in behalf of this Program in the past two years. The data generally in- 
Effects of Liquid Aliphatic and Aromatic Hydrocarbons on the Photosynthetic Rate of Phytoplankton.

\begin{tabular}{lccc}
\hline & $\begin{array}{c}\text { Conc. (ppm) needed } \\
\text { to cause 50\% } \\
\text { reduction in } \\
\text { photosynthesis }\end{array}$ & $\begin{array}{c}\text { Highest conc. } \\
\text { causing no effect }\end{array}$ & $\begin{array}{c}\text { Time } \\
\text { incubated }\end{array}$ \\
\hline Benzene Mixed ocean culture & 20 & 0.7 & $8 \mathrm{hrs.}$ \\
Benzene Mixed ocean culture & 60 & 5 & 7 \\
Benzene Mixed ocean culture & $\ldots$ & 3 & 8 \\
Toluene Mixed ocean culture & 3 & 0.1 & $71 / 2$ \\
Xylene Mixed ocean culture & 3 & 0.1 & 8 \\
Pentane Mixed ocean culture & 1 & 0.05 & 8 \\
Hexane Mixed ocean culture & 0.2 & 0.008 & 8 \\
Heptane Mixed ocean culture & 1.5 & 0.08 & 8 \\
Octane Mixed ocean culture & 0.02 & 0.008 & 8 \\
Benzene Skeletonema costatum & 200 & 10 & 7 \\
Benzene Skeletonema costatum & 300 & 10 & 8 \\
Benzene Skeletonema costatum & 80 & 11 & 8 \\
Toluene Skeletonema costatum & 20 & 2 & 8 \\
Hexane Skeletonema costatum & 0.3 & 0.07 & 9 \\
Octane Skeletonema costatum & 0.1 & 0.001 & 9 \\
Decane Skeletonema costatum & 0.005 & 0.001 & \\
\hline
\end{tabular}

dicate that the most important sources of $\mathrm{C}_{1}$ through $\mathrm{C}_{5}$ hydrocarbons are related to man's activities. These sources include ports and estuaries with their associated shipping and petrochemical activities, offshore drilling and production platforms, and ships which discharge oily ballast water and/or clean their fuel tanks at sea. The water column several miles distant from at least one example of each of the three types of sources showed several orders of magnitude higher concentrations than observed for the open Gulf.

On a March 1974 cruise, the Texas A\&M group surveyed the water in and around several groups of platforms offshore Louisiana. The groups farthest out, presumably the newest, showed $C_{1}-C_{5}$ dissolved hydrocarbon concentrations in nearby waters generally two to three orders of magnitude higher than concentrations in surface water of the open Gulf of Mexico, where the latter are equilibrium concentrations determined by the partial pressures of the various gases in the atmosphere. Surface water around platforms nearer to the coast. presumably in place for a longer period of time than the platforms cited above, had much lower levels but still one to two orders of magnitude higher than open Gulf surface water. 
Figure 1 shows the distribution of relative ethane concentrations (where the total open ocean surface values of $\mathrm{C}_{2}$ hydrocarbons are set equal to one) around a group of platforms located off the central Louisiana coast. All saturated $\mathrm{C}_{2}$ to $\mathrm{C}_{5}$ hydrocarbons, which are certainly petrogenic, as well as methane, which may also be formed biologically, showed approximately the same relative concentrations. The highest values, 85,000 times open ocean values or about $0.3 \mathrm{ml}$ of ethane per liter of sea water, were found near what appeared to be an underwater "flare." This phenomenon, a large volume of gas bubbling to the surface at one spot next to one platform, covered an area of several hundred square feet. This technique of disposing of gas appears to be a common one. High hydrocarbon levels, apparently from this one source, were observed in the surface water over an area greater than 25 square miles. This location was visited three times in four months with no apparent change in the appearance of this "flare" or the high levels of hydrocarbons in the surrounding water column.

On two subsequent cruises, four other flares were found, indicating

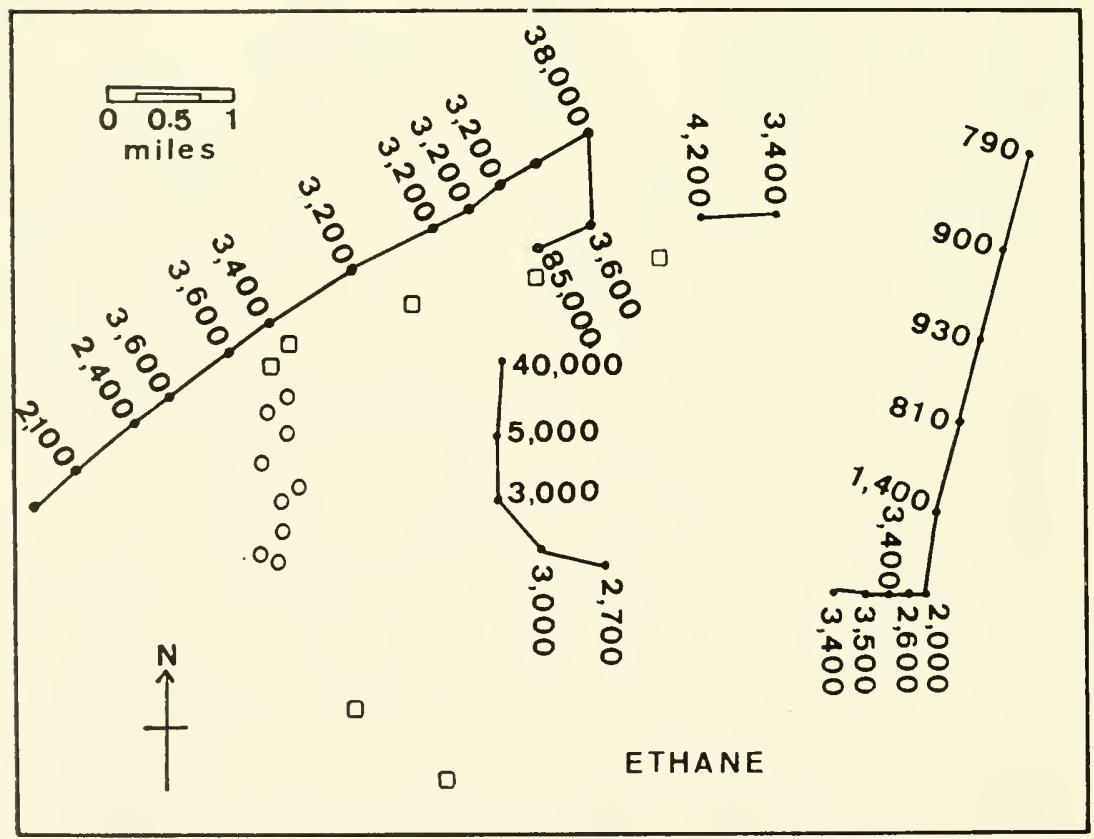

Figure 1. Relative ethane concentrations $\left(1-3 \times 10^{-6} \mathrm{ml}\right.$ of dissolved ethane at S.T.P. per liter of sea water) at $28^{\circ} 50^{\prime} \mathrm{N} 92^{\circ} 00^{\prime} \mathrm{W}$. Solid squares are locations of platforms; solid circles are exposed well heads. 
that this practice is, indeed, rather common in the Gulf. GC analysis of one of these gas emissions (flares) gave a complex spectrum which indicated carbon numbers up to at least $\mathrm{C}_{10}$ and included some aromatic components.

On the basis of this 5 year study in the Gulf of Mexico it appears that most instances of high levels of low-molecular-weight hydrocarbons in the vicinity of offshore oil production activities are due to this practice of underwater discharging waste hydrocarbon gases.

\section{Heavy Petroleum Hydrocarbons}

The group at the University of Texas Marine Science Institute find that sea water when equilibrated with a sample of \#2 fuel oil (API) becomes toxic in varying degrees to growth of representative types of microalgae including two blue-greens, a diatom, two greens, and a dinoflagellate (Pulich, Winters \& Van Baalen, 1974).

A standard petroleum containing seawater was prepared by equilibration of 1 part oil with 8 parts of sea water for 24 hours with gentle mixing by a magnetic stirring bar. After equilibration the water was drained by means of a stopcock at the base of the bottle. This stock of oil-treated seawater contained 10-20 ppm of total hydrocarbon depending on the oil used. The oil-treated stock searvater was diluted to obtain serial concentrations.

For a sensitive organism such as Thalassiosira pseudonana, strain $3 \mathrm{H}, 5 \mathrm{ml}$ of stock sea water (equilibrated with fuel oil so as to contain $15 \mathrm{mg} / \mathrm{l}$ of hydrocarbon) in $20 \mathrm{ml}$ of growth medium is lethal. If, as seems reasonable, the toxic component of the oil is $1-10 \%$ of the total dissolved hydrocarbon then $40-400 \mathrm{ppb}$ is toxic. This fuel oil-equilibrated seawater also inhibits photosynthesis in organism $3 \mathrm{H}$. For other microalgae tested (e.g. 580 and PR-6), similar effects on growth and photosynthesis were found but required higher concentrations of the oil-equilibrated sea water. Figure 2 shows a typical series of experiments and Table 2 is a summary of work using API \#2 fuel oil.

Water solubles from Kuwait or Southern Louisiana crudes (when the straight crude was equilibrated 1:8 with seawater) were not toxic, however specific fractions made by distillation did show some water soluble toxicity. Growth experiments in open (continuously bubbled) or sealed growth systems showed that most organisms were inhibited by varying amounts of these two crude oils when in direct contact with them. Organism 580 would not grow above 5 ul of Southern Louisiana/25 ml of medium, or $10 \mathrm{ul}$ of Kuwait $/ 25 \mathrm{ml}$ of medium (oil in direct contact with algae). 


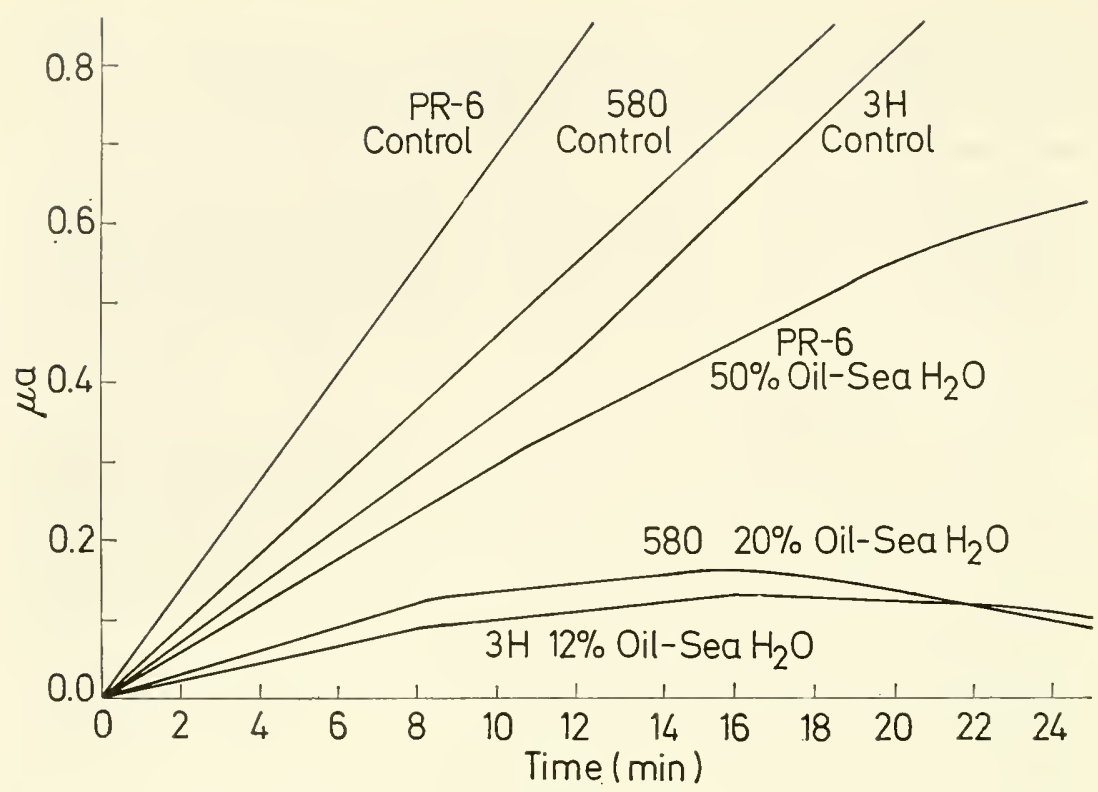

Figure 2. Effect of water solubles from No. 2 fuel oil on photosynthesis of 3 microalgae: Thalassiosira pseudonana (3H), Agmenellum quadruplicatum (PR-6), and Chlorella autotrophica (580). Conditions: No. 2 fuel oil equilibrated for 24th stirring with filtered seawater; seawater separated and filtered through $0.45 \mu \mathrm{m}$ Millipore filter and added to algal suspension $8 \mathrm{~min}$ before light turned on. Concentration of this water soluble fraction is given in percent, $\mathrm{v} / \mathrm{v}$ (e.g. $12.5 \%=1.4 \mathrm{ml}$ of algal suspension plus $0.2 \mathrm{ml}$ of seawater-oil solubles). Controls: seawater plus medium ASP-2. Algal strains are identified in Table 2. The algal concentrations for PR-6, $3 \mathrm{H}$ and for 580 are approximately $1 \times 10^{-} \mathrm{cells} / \mathrm{ml}$ in medium ASP-2. Electrode current at air saturation, medium ASP-2 $=3.4 \mu$ a. Light intensity, limited by Baird-A tomic Hot Mirror (34-01-2) to 350 to $800 \mathrm{~nm}$, was $580 \mathrm{~mW} / \mathrm{cm}^{2}$ at level of electrode chamber, measurement temperature $30^{\circ} \mathrm{C}$.

With both the sea water equilibrated with fuel oil and the crude oils, the toxic activity is mainly localized in medium and higher boiling fractions derived from distillation cuts from these materials.

The question of the toxicity of fuel oils to the microalgae has been examined in greater detail. Four fuel oil samples were obtained from Exxon Corporation. Approximately $50 \%$ of the compounds in the water solubles from these four fuel oils have been identified via gas chromatography and mass spectrometry. In addition to the well described types of compounds (naphthalenes and benzenes) expected in water soluable extracts phenols, anilines, and indoles were found 
Doubling Times (Hours) of Various Microalgae Grown in Sea Water Equilibrated With No 2 Fuel Oil. Numbers in Parentheses are Lag Times in Hours.

\begin{tabular}{|c|c|c|c|c|c|c|c|}
\hline \multirow{2}{*}{$\begin{array}{l}\text { Strain } 1 \\
\text { Desig- } \\
\text { nation }\end{array}$} & \multirow{2}{*}{$\begin{array}{c}\text { Basal } \\
\text { Me- } \\
\text { dium }^{1}\end{array}$} & \multirow{2}{*}{$\begin{array}{c}\text { Sea- } \\
\text { water } \\
\text { Con- } \\
\text { trol }\end{array}$} & \multicolumn{4}{|c|}{$\begin{array}{c}\text { Concentration of Seawater Equilibrated } \\
\text { with \#2 Fuel Oil }\end{array}$} & \multirow[b]{2}{*}{$50 \%$} \\
\hline & & & $0.5 \%$ & $5 \%$ & $10 \%$ & $25 \%$ & \\
\hline PR-6 & 3.9 & 3.9 & 3.9 & $3.9(4)$ & $3.9(7)$ & N.D. ${ }^{3}(72)$ & \\
\hline MAC & 6 & 9 & 9 & 9 & 9 & $9(10)$ & N.D.(96) \\
\hline $3 \mathrm{H}$ & 7.8 & 7.8 & 7.8 & 7.8 & $7.8(24)$ & $7.8(60)$ & \\
\hline Dun & 6.3 & 6.3 & 6.3 & 6.3 & 6.3 & 6.3 & N.D. (96) \\
\hline Ind. 580 & 9 & 9 & 9 & 9 & 9 & $9(16)$ & \\
\hline OBB & 50 & 50 & 50 & $50(120)$ & $50(170)$ & & \\
\hline
\end{tabular}

${ }^{1} \mathrm{PR}-6=$ Agmenellum quadruplicatum (blue-green), medium ASP-2 $+\mathrm{B}_{12}$ (6), temp. $39^{\circ}$, this laboratory.

MAC $=$ Nostoc sp. (blue-green), medium CG10 (7), temp. $39^{\circ}$, source (D.S. Hoare, U.T. Austin).

$3 \mathrm{H}=$ Thalassiosira pseudonana (diatom), medium ASP-2 $+\mathrm{B}_{12}+\mathrm{B}_{1}+\mathrm{Na}_{2} \mathrm{SiO}_{3}$. $5 \mathrm{H}_{2} \mathrm{O}$, temp. $30^{\circ}$, source (R. Guillard, Woods Hole).

Dun $=$ Dunaliella tertiolecta (green), medium ASP-2 $+\mathrm{B}_{12}+\mathrm{B}_{1}$, temp. $32^{\circ}$, source (R. Guillard, Woods Hole).

Ind. $580=$ Chlorella autotrophica (green), medium ASP-2 $+\mathrm{B}_{12}+\mathbf{B}_{1}$, temp. $30^{\circ}$, source (R. Guillard, Woods Hole).

$\mathrm{OBB}=$ Gymnodinium halli (dinoflagellate), modified medium NH15 (8), temp. $30^{\circ}$, source (B. Wilson, Texas A\&M, Galveston).

Forty $\mathrm{ml}$ of \#2 Fuel Oil layered on $320 \mathrm{ml}$ filtered (Gelman type A) off-shore sea water, the whole stirred gently for 24 hours at room temperature, sea water layer removed and refiltered through $0.45 \mu \mathrm{m}$ Millipore filter. This sea water equilibrated with \#2 fuel oil has $15 \mathrm{mg}$ total extractables/liter. Note that $50 \%$ designates 1 part of algal media plus 1 part sea water saturated with API \#2 fuel oil, etc.

${ }^{3}$ N.D. $=$ Not determined.

(Table 3). Of these classes of compounds methyl, dimethyl, and trimethyl derivatives are present in relatively high concentration.

Data indicated that anilines and phenols were extracted from oil into sea water at a faster rate than naphthalenes or indoles.

The water solubles from the four fuel oils showed considerably different inhibitory effects to growth of six microalgae, two blue-greens, two greens, and two diatoms. Two of the fuel oil extracts, Baytown and Montana, were lethal for blue-green algae. This was in part traceable to their content of p-toluidine which was found to be toxic to Agmerellum quadruplicatum, Strain PR-6, at a level of $1 \mathrm{ug}$ in the algal lawnpad assay and $100 \mathrm{ug} /$ liter in liquid culture. The water soluble frac- 
Identification and Concentration of Major Components in the Water Soluble Fractions of Four Fuel Oils.

\begin{tabular}{|c|c|c|c|c|}
\hline & Montana & Baytown & New Jersey & $\begin{array}{l}\text { Baton } \\
\text { Rouge }\end{array}$ \\
\hline Total Organics & $16^{*}$ & 19 & 14 & 9 \\
\hline $\begin{array}{l}\text { Naphthalenes } \\
\text { (Naphthalene, } \\
\text { Methyl and Dimethyl) }\end{array}$ & 1.48 & 1.80 & 2.51 & 1.56 \\
\hline $\begin{array}{l}\text { Phenols } \\
\text { (Cresols, Di and Trimethyl) }\end{array}$ & 2.33 & 4.12 & 1.96 & 1.08 \\
\hline $\begin{array}{l}\text { Anilines } \\
\text { (Toluidines. Di and } \\
\text { Trimethyl) }\end{array}$ & 2.57 & .72 & .27 & .02 \\
\hline $\begin{array}{l}\text { Indoles } \\
\text { (Indole. Methyl, Di } \\
\text { and Trimethyl) }\end{array}$ & .79 & .09 & .32 & .05 \\
\hline
\end{tabular}

* All values are in $\mathrm{mg}$ of organic per lt. of sea water.

tion from New Jersey fuel oil was lethal to the two green algae. with lesser effects on the two blue-greens. The two estuarine diatoms used as test organisms were not greatly inhibited by Baytorvn, Montana, or New Jersey fuel oil water soluble extracts. However, earlier work with an American Petroleum Institute fuel oil and the diatom. Thalassiosira pseudonana $(3 \mathrm{H})$ showed that $3 \mathrm{H}$ was a very sensitive organism. Water solubles from the Baton Rouge fuel oil were almost without effect on the growth of all six microalgae. On the basis of the work herein and earlier work a very cautious viewpoint is advisable in generalizing on the toxicity or lack thereof of a given fuel oil on the growth of different kinds of microalgae. On the other hand water solubles from toxic fuel oils such as Baytown or New Jersey the data clearly suggest that their potential for environmental damage is high either through selective or enrichment effects on natural populations or through a lowering of total primary production.

At Florida State University, the effects on growth rates of marine bacteria, Serratia marinorubra and Vibrio parahaemolyticus have been determined for a variety of aromatic hydrocarbons. In general, the least soluble hydrocarbons have the greatest effect on a per molecule basis. For example, benzopyrene at a concentration of $1.2 \mathrm{ppb}$ displayed toxicity similar to naphthalene at $5.9 \mathrm{ppm}$. (Both of the above concentrations represent $20 \%$ of saturation in sea water at $35 \%$ salin- 
ity and $25^{\circ} \mathrm{C}$.) It was observed that for each additional aromatic ring. the concentration of an aromatic hydrocarbon necessary to produce a toxic effect decreased by approximately one order of magnitude. For a given aromatic ring system, the addition of alkyl side chains also decreased the concentration required to produce toxicity. This effect was less predictable in that not only the number of side chains and the number of carbons they contain but also their positions on the ring control the toxicity of the molecule. Similar experiments with the microalga Cyclotella menighiana indicated that this organism was more susceptible to aromatic hydrocarbons than the bacteria. For example, $8 \mathrm{ppm}$ naphthalene only reduced the growth rate of the bacteria but completely killed $C$. menighiana. Other experiments have shown that the aromatic hydrocarbons which were tested can interfere with the ability of marine bacteria to take up substrates such as glutamic acid and cause the leakage of metabolites such as the amino acids from the cells.

In a later series of experiments. the toxicity to marine bacteria of the water soluble fractions of whole crude and refined oils was examined by the FSU group. Five oils, Southern Louisiana. Kuwait, and Florida Jay crude oils, bunker C and No. 2 fuel oil, were used in this study. Both growth rate and final cell density were determined turbidimetrically for controls and bacteria exposed to the water soluble fractions of the above oils. For each oil, the reduction in growth rate and cell density were normalized to $1 \mathrm{ppm}$ of total water soluble material or $1 \mathrm{ppb}$ of total aromatic hydrocarbon (equivalent to benzene eluant from silica gel). When all measures of toxicity were taken into account, the relative toxicity of each of the oils was calculated to be as follows:

Concentration of Aromatic Relative Toxicity Hydrocarbons in Oil

\section{Oil}

Florida Jay

So. La. Crude

Kuwait Crude

No. 2 Fuel Oil

Bunker C

$$
\text { of WSF }
$$

100

67

32

31

26 Equilberated Sea Water (ppb)

Even though the aromatic hydrocarbons are known toxicants. the relative toxicity of the water soluble fraction of these oils is unrelated to the concentration of aromatic hydrocarbons in seawater equilibrated with the oil. Most of the components of the water soluble frac- 
tion are non-hydrocarbons, and do not elute from silica gel in either hexane or benzene. These components may be largely responsible for the toxicity of the test oils to marine bacteria. This observation also made by the UT group for algae may have important implications for our understanding of the mechanism of oil spill damage.

It was observed that for any given oil, the toxicity to marine bacteria was dependent on the concentration of organic nutrients available to the bacteria. When data from all 5 oils were averaged, the following numbers were calculated:

Conc. of yeast extract in culture medium $(\%)$

$$
\begin{aligned}
& 0.1 \\
& 0.05 \\
& 0.01
\end{aligned}
$$

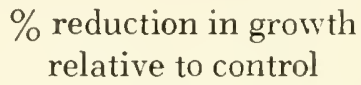

$10 \%$
$20 \%$
$50 \%$

Low organic nutrients were accompanied by a greater relative toxicity to marine bacteria in the presence of water soluble fractions of oil. Although it is not legitimate to extrapolate the above data to the very low concentration of dissolved organic matter typically found in the oceans, it is clear that the concentration of water soluble fraction required to produce toxicity in the ocean should be much lower than concentrations required in laboratory experiments.

When bacteria which had been grown in the presence of WSF's at each of the yeast extract concentrations above were re-inoculated into media without WSF, their growth was equal to or of ten better than untreated controls.

\section{Hydrocarbon Solubility}

Since hydrocarbons dissolved in seawater are toxic, it is important to establish the solubility of several types of hydrocarbon molecules. The Florida State University group has made these measurements.

The true solubilities of several aliphatic and aromatic hydrocarbons were determined in both distilled water and seawater (Table 4). In most cases, the seawater solubilities represent new additions to the literature. It was determined that the solubility of the aromatic hydrocarbons was related most closely to their molar volume and Lewis basicity. These hydrocarbons are "salted out" with increasing salinity and the salting coefficients were the same whether the hydrocarbons existed in pure solution or in simple mixtures.

The Florida group studied the levels of hydrocarbons in ocean 
Solubility of Individual Hydrocarbons at $25.0^{\circ} \mathrm{C}$ in Distilled and Seawater.

\begin{tabular}{lcc}
\hline \multicolumn{1}{c}{ Compound } & Distilled Water & Seawater \\
\hline Dodecane & $3.7 \mathrm{ppb}$ & $2.9 \mathrm{ppb}$ \\
Tetradecane & 2.2 & 1.7 \\
Hexadecane & 0.9 & 0.4 \\
Octadecane & 2.1 & 0.8 \\
Eicosane & 1.9 & 0.8 \\
Hexacosane & 1.7 & 0.1 \\
Toluene & $534.8 \pm 4.9 \mathrm{ppm}$ & $379.3 \pm 2.8 \mathrm{ppm}$ \\
Ethylbenzene & $161.2 \pm 0.9$ & $11.0 \pm 1.3$ \\
o-Xylene & $170.5 \pm 2.5$ & $129.6 \pm 1.8$ \\
m-Xylene & $146.0 \pm 1.6$ & $106.0 \pm 0.6$ \\
p-Xylene & $156.0 \pm 1.6$ & $110.9 \pm 0.9$ \\
Isopropylbenzene & $65.3 \pm 0.8$ & $42.5 \pm 0.2$ \\
1, 2, 4-Trimethylbenzene & $59.0 \pm 0.8$ & $39.6 \pm 0.5$ \\
1, 2. 3-Trimethylbenzene & $75.2 \pm 0.6$ & $48.6 \pm 0.5$ \\
1,3,5-Trimethylbenzene & $48.2 \pm 0.3$ & $31.3 \pm 0.2$ \\
n-Butylbenzene & $11.8 \pm 0.1$ & $7.1 \pm 0.1$ \\
s-Butylbenzene & $17.6 \pm 0.2$ & $11.9 \pm 0.2$ \\
t-Butylbenzene & $29.5 \pm 0.3$ & $21.2 \pm 0.3$ \\
Naphthalene & $31.3 \pm 0.4$ & $22.0 \pm 0.3$ \\
Biphenyl & $7.5 \pm 0.1$ & $4.8 \pm 0.1$ \\
Phenanthrene & $1.1 \pm 0.01$ & $0.7 \pm 0.03$ \\
\hline
\end{tabular}

Sutton and Calder, 1974, 1975; Eganhouse and Calder, 1975

waters. Concentrations of dissolved non-polar hydrocarbons extracted from waters taken at several stations and depths in the Gulf of Mexico and Caribbean Sea ranged from traces to $75 \mathrm{ppb}$, with the highest occurring in the Florida Strait. These concentrations were determined gravimetrically. In all cases except in the Florida Strait this fraction was characterized by relatively large amounts of $\mathrm{n}$-alkanes having between 15 and 20 carbon atoms and relatively small amounts of n-alkanes with more than 20 carbon atcms. In the Florida Strait there were much higher concentrations of n-alkanes above $\mathrm{C}_{20}$ (Table 5). There was an unresolved envelope in the gas chromatograms of all the samples that extended approximately from the $C_{15}$ to the $C_{30}$ position, with the maximum between $\mathrm{C}_{20}$ and $\mathrm{C}_{23}$ positions (Iliffe \& Calder, 1974). While these are fairly high values, they are still below the solubility values. In a later study, additional samples were collected from the Florida Strait and filtered through pre-combusted Whatman $\mathrm{GF} / \mathrm{F}$ filters. The compositional features of the dissolved non-polar 
Hydrocarbons in Natural Seawater* $(p p b)$.

\begin{tabular}{|c|c|c|c|}
\hline Station & Depth $(\mathrm{m})$ & $\begin{array}{c}\text { Dissolved } \\
\text { extractable matter }\end{array}$ & $\begin{array}{c}\text { Non-polar } \\
\text { hydrocarbon }\end{array}$ \\
\hline \multirow{7}{*}{ Florida Strait } & 1 & & 52 \\
\hline & 107 & 291 & 38 \\
\hline & 144 & 180 & 75 \\
\hline & 213 & 196 & 16 \\
\hline & 269 & 117 & 54 \\
\hline & 500 & 121 & trace \\
\hline & Average & 181 & 47 \\
\hline \multirow{5}{*}{ Mid-Gulf } & 1 & 84 & 12 \\
\hline & 75 & 318 & . \\
\hline & 150 & 78 & 7 \\
\hline & 225 & 215 & 18 \\
\hline & 500 & 75 & 13 \\
\hline \multirow{7}{*}{ Yucatan Strait } & Average & 154 & 12 \\
\hline & 1 & 210 & 24 \\
\hline & 100 & 358 & trace \\
\hline & 128 & 202 & trace \\
\hline & 200 & 279 & 4 \\
\hline & 500 & 224 & 9 \\
\hline & Average & 255 & 12 \\
\hline Cariaco Trench & 900 & 357 & 5 \\
\hline Caribbean & 200 & 124 & 8 \\
\hline
\end{tabular}

* Iliffe \& Calder, 1974

hydrocarbons (hexane eluant from silica gel) were similar to the first study. while the concentration of this fraction was lower, generally 4 ppm or less (concentrations were calculated from gas chromatographic peak areas in this case.) The dissolved aromatic hydrocarbons and polyolefins (benzene eluant from silica gel) occurred at 4 ppb or less and gave a complex GC spectra with most components eluting after naphthalene and before pyrene. The micro-particulates on the filter pad were similarly analyzed and found to contain 1 to 1.5 times the concentration of dissolved hydrocarbons.

\section{Phthalate Esters}

Dialkyl phthalates are abundantly produced for use as plasticizers. 
At the onset of this program, there were indications that the phthalate esters were present in high concentrations in the environment and that they were toxic to aquatic organisms. Texas A\&M investigators were concerned with the impact of phthalate esters on the marine environment. Since phthalate levels in the open ocean had not been reported prior to this study, data was needed to establish the dosage-levels to be used in the laboratory studies of effects on marine life. The analysis

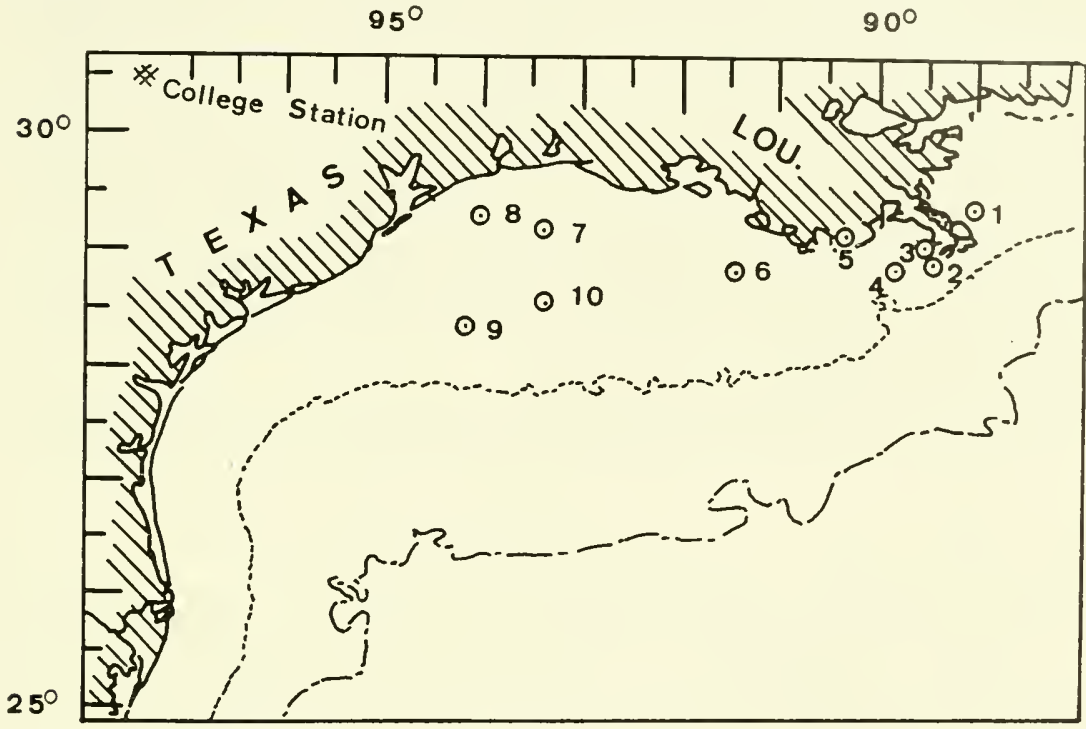

Figure 3. DEHP levels in biota, water and sediment from selected locations in the Gulf of Mexico*.

\begin{tabular}{|c|c|c|c|}
\hline \multirow[b]{2}{*}{ STATION } & \multicolumn{3}{|c|}{ DEHP } \\
\hline & $\begin{array}{l}\text { Biota† } \\
\mathrm{ppb}\end{array}$ & $\begin{array}{c}\text { Water } \\
\text { ppt }\end{array}$ & $\begin{array}{c}\text { Sediment } \\
\text { ppb }\end{array}$ \\
\hline 1 & 4.0 & 55. & 2.0 \\
\hline 2 & 9.0 & 30. & 173 \\
\hline 3 & 14.0 & 23. & 176 \\
\hline 4 & 3.0 & . & 6.5 \\
\hline 5 & 2.3 & 316. & $<2.0$ \\
\hline 6 & 2.5 & $1+4$. & \\
\hline 7 & 2.0 & 135. & \\
\hline 8 & 4.0 & 143. & \\
\hline 9 & 2.0 & 100. & $<2.0$ \\
\hline 10 & 3.0 & 68. & . \\
\hline
\end{tabular}

* Giam, et al., 1975.

+ Mainly fish. 
of samples from the Gulf of Mexico for these esters was undertaken. Reported analytical procedures, however, were not satisfactory to quantitate the very low levels present in open-ocean samples. Also, other ubiquitous pollutants, such as the polychlorinated hydrocarbons (PCBs, DDT, DDE), were expected to interfere with the reported gas chromatographic analyses of phthalates. Thus, appropriate separation and other techniques were necessary prior to carrying out such analysis. Using a combination of solvent partitioning, deactivated-Florisil column chromatography and electron-capture gas chromatography, botl chlorinated hydrocarbons and phthalate esters can be separated, detected and quantitated at the parts per billion ( $p p b$ ) level in biota and sediment, and the parts per trillion (ppt) level in water. (Giam et al., 1975). Data on samples from the Gulf of Mexico indicates that the level of the most predominant phthalate ester. DEHP, di-2-ethylhexyl phthalate, in biota and sediment are in the low ppb range and in the low ppt range in water. The results of some of these analyses are presented in Figure 3. This finding is consistent with the levels for other organic pollutants in this area.

Studies on the effects of phthalates on plankton have been initiated;

TABLE 6

Growth Inhibition by Phthalates.

\begin{tabular}{lcccccccc}
\hline & AMT. & & & & & & \\
ORGANISM $^{1}$ & ON PAD & DMP & DEP & DPP & DBP & DEHP & DIIP & PA $^{2}$ \\
\hline Blue-green PR-6 & $0.1 \mathrm{mg}$ & $0^{3}$ & 0 & 3 & 0 & 0 & 0 & 0 \\
& $1.0 \mathrm{mg}$ & 11 & 9 & 6 & 0 & 0 & 0 & 3 \\
Green alga & $10.0 \mathrm{mg}$ & $20-23$ & $11-13$ & 7 & 0 & 0 & 0 & 36 \\
Strain 580 & $0.1 \mathrm{mg}$ & 0 & 0 & $30-36$ & 1 & 0 & 0 & 0 \\
& $1.0 \mathrm{mg}$ & $5-8$ & 13 & 36 & 1 & 0 & 0 & 0 \\
Diatom & $10.0 \mathrm{mg}$ & $20-25$ & 17 & 36 & 1 & 0 & 0 & $30-34$ \\
(Cylindrotheca) & $0.1 \mathrm{mg}$ & 0 & 0 & 4 & 1 & 0 & 0 & 0 \\
N-1 & $1.0 \mathrm{mg}$ & 3 & 7 & 6 & 2 & 0 & 0 & 0 \\
& $10.0 \mathrm{mg}$ & 12 & 10 & 6 & 2 & 0 & 2 & $5-12$ \\
\end{tabular}

${ }^{1}$ PR-6-Agmenellum quadruplicatum (Marine coccoid blue-green)

580 - Chlorella autotrophica (green alga)

N-1-Cylindrotheca sp. (Diatom)

2DMP =Dimethyl-; DEP=Diethyl; DPP=Dipropyl-; DEHP-Di-2-ethylhezyl-;

$\mathrm{DIIP}=$ Diisodecyl-phthalate; $\mathrm{PA}=$ Phthalic Acid.

${ }^{3} \mathrm{O}=$ no inhibition; other numbers indicate diameter of zone of inhibition out from pad in $\mathrm{mm}$, complete inhibition of growth on plate equals $36 \mathrm{~mm}$. 
investigations using other organisms are described later. The species chosen for initial screening were a blue-green algae, Strain PR-6, a green algae, Strain 580 and a Diatom, Strain N-1 (Cyclindrotheca). The zone of inhibition of growth of these organisms around discs to which selected phthalates were applied was the initial screening procedure. These preliminary studies indicate that the lower phthalate analogs. dimethyl, diethyl and di-n-propyl phthalates, have some effect on the growth of these organisms. Table 6 summarizes early results. 


\section{Biological Effects: Marine Animals}

A major goal of the Program is to determine the effects of sublethal concentrations of pollutants on marine animals including sperm, eggs and larvae. All investigators have found it necessary to establish lethal levels for several organisms then to proceed to evaluate parameters such as reproduction, growth and various physiological responses as indicators of pollutant effects. The state of our knowledge does not promise that mechanisms of uptake, toxic activity and detoxification will be soon discovered. Several more immediate problems which can be resolved include the relative sensitivity of larvae vs adults and estuarine vs open ocean organisms for various pollutants.

\section{Heavy Hydrocarbons}

Texas A\&M investigators have provided the Program with samples of four American Petroleum Institute standard oils and their hydrocarbon composition (Table 7 ). These data support the view of all investigators that the water soluble fraction of oil is of concern and should be studied in depth. These oils and selected pure compounds have been used by the Texas A\&M group to determine the lethal concentration $\left(96 \mathrm{hr} . \mathrm{LC}_{50}\right.$ ) for a variety of organisms some of which are given in Table 8 . Test species were selected on the basis of their significance in the food web, their diversity of taxa, their abundance in the environment and their ability to survive, and in some cases reproduce successfully in the laboratory. The experiments indicate that the high aromatic \#2 fuel oil and the Bunker $\mathrm{C}$ oil are the more toxic materials (see also Anderson et al., 1974). In these studies there is a difference of 2-3 orders of magnitude between adults and fry of Cyprinodon variegatus. In nearly all cases, $\mathrm{LC}_{50}$ values are significantly higher than levels of oil in the oceanic environment. However. in areas of oil production or dumping and certainly in some estuaries these levels are within the range encountered by animals.

When exposed to dispersed \#2 fuel oil in sea water. oysters rapidly accumulated a wide spectrum of different hydrocarbons in experiments carried out by Texas A\&M investigators (Table 9). The mono-, di-, and tri-methylnaphthalenes were accumulated more than the other di- and tri-aromatic hydrocarbons or individual paraffins. When 
The Concentrations of $C_{12}-C_{2,4} N$-Paraffins and Di-Tri-Aromatic Hydrocarbons in the Test Oils and in Water-Soluble Fractions (WSFs) Prepared From Them.

$H_{y}$ drocarbon Concentrations in the Oils are Given as Percent $(\mathrm{g} / 100 \mathrm{ml})$ and in the WSFs as Parts Per Billion $(\mu \mathrm{g} / \mathrm{L})$ in $20 \%$ Seawater.

\begin{tabular}{|c|c|c|c|c|c|c|c|c|}
\hline Name of Compound & $\begin{array}{l}\text { S. Lou } \\
\text { Whole } \\
\text { Oil } \\
(\%)\end{array}$ & $\begin{array}{l}\text { isiana } \\
\text { WVSF } \\
(\mathrm{ppb})\end{array}$ & $\begin{array}{c}\text { Ku } \\
\text { Whole } \\
\text { Oil } \\
(\%)\end{array}$ & $\begin{array}{r}\text { WSF } \\
(\mathrm{ppb})\end{array}$ & \multicolumn{2}{|c|}{$\begin{array}{l}\text { \#2 Fuel Oil } \\
\text { Whole }\end{array}$} & \multicolumn{2}{|c|}{$\begin{array}{l}\text { Bunker C } \\
\text { Whole }\end{array}$} \\
\hline n-paraffins & & & & & & & & \\
\hline $\mathrm{C}_{11}$ & 0.44 & 10.0 & 0.46 & $<0.5$ & 0.82 & 5.0 & 0.11 & 0.8 \\
\hline $\mathrm{C}_{15}$ & 0.48 & 10.0 & 0.41 & $<0.5$ & 1.06 & 7.0 & 0.11 & 0.9 \\
\hline $\mathrm{C}_{16}$ & 0.54 & 12.0 & 0.43 & 0.6 & 1.20 & 8.0 & 0.15 & 1.2 \\
\hline $\mathrm{C}_{1 \tau}$ & 0.41 & 9.0 & 0.42 & 0.8 & 0.98 & 6.0 & 0.12 & 1.9 \\
\hline $\mathrm{C}_{18}$ & 0.30 & 7.0 & 0.28 & 0.5 & 0.60 & 4.0 & 0.10 & 1.0 \\
\hline $\begin{array}{c}\text { Total } \mathrm{C}_{12}-\mathrm{C}_{2+} \\
\text { n-paraffins }\end{array}$ & 3.98 & 89.0 & 4.00 & 2.9 & 7.38 & 47 & 1.26 & 12 \\
\hline aroniatics & & & & & & & & \\
\hline naphthalene & $0.0+$ & 120 & 0.04 & 20 & 0.40 & 840 & 0.10 & 210 \\
\hline 1-methylnaph thalene & 0.08 & 60 & 0.05 & 20 & 0.82 & 340 & 0.28 & 190 \\
\hline 2-methylnaphthalene & 0.09 & 50 & 0.07 & 8.0 & 1.89 & 480 & 0.47 & 200 \\
\hline dimethylnaphthalenes & 0.36 & 60 & 0.20 & 20 & 3.11 & 240 & 1.23 & 200 \\
\hline trimethylnaphthalenes & 0.27 & 8.0 & 0.19 & 3.0 & 1.84 & 30 & 0.88 & 100 \\
\hline biphenyls & $<0.01$ & 2.0 & $<0.01$ & 1.0 & 0.16 & 28 & $<0.01$ & 1.0 \\
\hline fluorenes & 0.02 & $<1.0<$ & $<0.01$ & $<1.0$ & 0.36 & 20 & 0.24 & 11.0 \\
\hline phenanthrenes & 0.06 & 4.0 & 0.04 & 3.0 & 0.53 & 20 & 1.11 & 23.0 \\
\hline dibenzothiophene & 0.02 & 1.0 & 0.01 & $<1.0$ & 0.07 & 4.0 & $<0.01$ & $<1.0$ \\
\hline Total aromatics & 0.94 & 305 & 0.60 & 75 & 9.18 & 2,002 & 4.31 & 935 \\
\hline Total hydrocarbons measured & 4.92 & 394 & 4.60 & 78 & 16.56 & 2,049 & 5.57 & 947 \\
\hline $\begin{array}{l}\text { Total hy-drocarbons } \\
\text { present (IR analysis) }\end{array}$ & & 19.800 & & 0,400 & & 8,700 & & 6,300 \\
\hline
\end{tabular}

J. IV. Anderson, et al., 1974.

the oysters were returned to oil-free sea water they released $90 \%$ of the accumulated paraffins in 24 hours and naphthalenes in 28 days.

Similar patterns of petroleum hydrocarbon accumulation and release were observed in several other species of invertebrates and fish. Regardless of the animal or test oil utilized, the hydrocarbons accumulated to the greatest degree and retained the longest were the naphthalenes. The time required for complete depuration varied with the species involved, the length of exposure and the concentration and composition of the exposure mixture. In general shrimp and fish, when 
TABLE 8

Relative Toxicities of Oils, Their Water-Soluble Fractions and Specific Hydrocarbons on Two Species of Marine Animals.

\begin{tabular}{|c|c|c|c|c|c|c|}
\hline \multirow[b]{5}{*}{ Oils } & \multicolumn{6}{|c|}{$\mathrm{LC}_{50}(\mathrm{ppm})$} \\
\hline & \multirow{3}{*}{\multicolumn{3}{|c|}{$\begin{array}{l}\text { Palaemonetes } \\
\text { (grass shrimp) } \\
\text { HOURS }\end{array}$}} & \multirow{3}{*}{\multicolumn{3}{|c|}{$\begin{array}{c}\text { Cyprinodon } \\
\text { (sheepshead minnow) } \\
\text { HOURS }\end{array}$}} \\
\hline & & & & & & \\
\hline & & & & & & \\
\hline & 24 & 48 & 96 & 24 & 48 & 96 \\
\hline \multicolumn{7}{|l|}{ South Louisiana } \\
\hline OWD* & 1507 & 1440 & 283 & 80,000 & 33,000 & 29,000 \\
\hline WSF & $>16.8$ & $>16.8$ & $>16.8$ & 19.8 & 19.8 & 19.8 \\
\hline \multicolumn{7}{|l|}{ Kuwait } \\
\hline OWD & 16,000 & 10,000 & 6,000 & 80,000 & 80,000 & 80,000 \\
\hline WSF & $>10.2$ & $>10.2$ & $>10.2$ & , & . & \\
\hline \multicolumn{7}{|l|}{ \#2 fuel oil } \\
\hline OWD & 7.7 & 5.5 & 4.1 & 250 & 200 & 93 \\
\hline WSF & 3.8 & 3.4 & 3.1 & 6.9 & 6.9 & 6.3 \\
\hline \multicolumn{7}{|l|}{ Bunker C } \\
\hline \multicolumn{7}{|l|}{ OWD } \\
\hline WSF & 3.6 & 3.4 & 3.1 & 4.7 & 4.4 & 3.1 \\
\hline \multicolumn{7}{|l|}{ Specific Hydrocarbons } \\
\hline Benzene & 33.0 & 33.0 & 23.0 & 22.9 & & \\
\hline $1,2,4$, trimethyl-benzene & 8.0 & 5.7 & 5.7 & 7.5 & & . \\
\hline Phenol & 42.0 & 20.0 & 6.0 & $10-20$ & & . \\
\hline Naphthalene & 2.3 & 2.3 & & 2.4 & . & . \\
\hline 1-Methylnaphthalene & 1.1 & 1.0 & 0.8 & 3.0 & & \\
\hline 2-Methylnaphthalene & - & & & 2.3 & & \\
\hline Dimethylnaphthalene & 0.7 & 0.7 & 0.7 & $<5.1$ & & \\
\hline Cyclohexane Carboxylic acid & $\ldots$ & $\ldots$ & & 200 & . & . \\
\hline Dodecyl Sodium Sulfate (DSS, & & & & & & \\
\hline standard reference toxicant) & 135.0 & 108.0 & 108.0 & 10 & 9.0 & 9.0 \\
\hline
\end{tabular}

* OWD is oil-water dispersion, WSF is water-soluble fraction.

returned to oil-free sea water, released the accumulated petroleum hydrocarbons rapidly. A few days or weeks were required for complete depuration. Oysters and clams, on the other hand, released the accumulated hydrocarbons very slowly, requiring in some cases, one to two months for complete depuration.

The fish, Fundulus similus, showed varying degrees of tolerance to exposure to the water-soluble fraction of No. 2 fuel oil. The less tolerant fish accumulated substantially higher concentrations of naphthalenes in their tissues than did the tolerant fish. The sensitive fish had particularly high concentrations of naphthalenes in the gall bladder, heart, liver and brain. The results strongly suggest that the sen- 
Table 9

Concentrations of Different Petroleum Hydrocarbons in the Tissues of Oysters Crassostrea virginica after 8 hours Exposure to a \#2 Fuel Oil-In-Water Dispersion and at

Different Times Following Return to Oil-Free Sea Water

\begin{tabular}{|c|c|c|c|c|c|c|c|c|c|c|c|c|c|c|c|}
\hline $\begin{array}{l}\text { Time } \\
\text { (hrs.) }\end{array}$ & $\mathrm{n}-\mathrm{P}$ & $N$ & $1-M N$ & 2.MN & $\begin{array}{l}\text { Petroleu } \\
\text { DMIN }\end{array}$ & $\begin{array}{c}\text { im Hydr } \\
\text { TMIN }\end{array}$ & $\begin{array}{c}\text { ocarbon } \\
B\end{array}$ & $\begin{array}{c}\text { Concent } \\
\text { MB }\end{array}$ & $\stackrel{\text { ration }}{\mathrm{F}}$ & $\begin{array}{l}\text { (ug/g w w } \\
\text { MFF }\end{array}$ & $\begin{array}{l}\text { et wl.) } \\
\text { DBT }\end{array}$ & $\mathrm{P}$ & MP & DMP & Tolal \\
\hline \multicolumn{16}{|c|}{ Exposure } \\
\hline 0 & . & 0.2 & 0.1 & 0.3 & 1.0 & 0.8 & $\ldots$ & & $\ldots$ & & & & & & 2.4 \\
\hline 8 & 235 & 14.7 & 8.7 & 15.0 & 21.8 & 9.1 & 0.3 & 0.5 & 1.0 & 1.2 & 0.3 & 1.9 & 1.9 & 0.3 & 312 \\
\hline \multicolumn{16}{|c|}{ Depuration } \\
\hline 3 & 156 & 12.0 & 8.4 & 12.0 & 22.7 & 10.8 & 0.3 & 0.4 & 0.7 & 0.7 & 0.3 & 1.3 & 1.3 & 0.2 & 228 \\
\hline 6 & 68 & 7.3 & 5.1 & 7.3 & 13.2 & 5.7 & 0.1 & 0.2 & 0.4 & 0.2 & 0.1 & 0.6 & 0.6 & 0.1 & 109 \\
\hline 24 & 18 & 6.5 & 5.7 & 7.6 & 14.8 & 9.5 & 0.2 & 0.2 & 0.5 & 0.7 & 0.2 & 1.2 & 1.3 & 0.3 & 67 \\
\hline 120 & 10 & 8.2 & 4.7 & 6.8 & 13.4 & 4.9 & 0.1 & 0.1 & 0.2 & 0.1 & 0.1 & 0.4 & 0.4 & 0.2 & 54 \\
\hline 672 & . & . & & 0.1 & 0.5 & 0.9 & & & . & $\ldots$ & . & . & & & 1.5 \\
\hline
\end{tabular}

* n-P, n-paraffins; N, naphthalene; 1-MN, 2-MN, 1 methyl- and 2-methlynaphthalenes; $\mathrm{DMN}$, dimethylnaphthalene; TMN, trimethylnaphthalene; B, biphenyl, MB, methylbiphenyl; $\mathrm{F}$, fluorene, MF, methylfluorene; DBT, dibenzothiophene; $\mathrm{P}$, phenanthrene; MP, methylphenanthrene; DMP, dimethylphenanthrene.

sitive fish have gill surfaces more permeable to hydrocarbons and that hydrocarbon accumulation in the brain and heart result in respiratory depression or narcosis. When surviving fish were returned to oil-free sea water, they recovered rapidly. The high concentrations of naphthalenes in the gall bladder indicate that the liver-gall bladder system is an important avenue of naphthalene excretion in fish. Although hydrocarbon accumulation appears to occur primarily across the gill surfaces, feeding experiments have shown that substantial uptake can also occur through the digestive tract. The gut may represent an important uptake route in those marine fish which actively drink sea water.

Similar studies with brown shrimp Penaeus aztecus indicate that the majority of accumulated naphthalenes is associated with the digestive gland soon after exposure begins and this organ retains the compounds for the longest period following exposure. When shrimp are returned to oil-free sea water, the tissues other than the digestive gland released the accumulated naphthalenes rapidly and the edible muscular abdomen is one of the first body regions to depurate to background levels. It may be that the relatively rapid release of naphthalenes by fish and crustaceans is partially due to active detoxification and excretion mechanisms. The slower release rates exhibited by bivalves 
(clams and oysters) suggest that similar detoxification pathways are not present in these less complex species.

Since naphthalenes appeared to be important petroleum hydrocarbons from the standpoint of toxicity and tissue retention, the relationship between exposure water and tissue naphthalenes concentrations and respiratory response was investigated by the Texas A\&M group. The respiratory response of several species to oil exposure was evaluated. The only species studied which consistently demonstrated abnormal oxygen consumption rates in response to exposure to oil was the mysid Mysidopsis almyra. In this species oil exposure always resulted in respiratory rates significantly higher than control values. It is interesting that during exposure to both the WSFs (water soluble fraction) and OWDs (oil-water-dispersal) of No. 2 fuel oil, the maximum respiratory rate occurred at an exposure concentration of 0.40 ppm total naphthalenes.

An attempt was made in subsequent experiments to correlate abnormal respiratory responses to the concentration of oil-derived naphthalenes in the tissues of the experimental animals. When postlarval brown shrimp Penaeus aztecus vere exposed to a 30\% WSF of No. 2 fuel oil for 4 hours, they accumulated high concentrations of naphthalenes in their tissues and had respiratory rates significantly higher than those of controls. After a recovery period of 27 hours in oil free sea water, the shrimp still contained approximately $6.2 \mathrm{ppm}$ napluthalenes and had respiratory rates still significantly above those of controls. In another experiment, grass shrimp Palaemonetes pugio were exposed to a dilute of No. 2 fuel oil OWD $(0.10 \mathrm{ppm}$ total naphthalenes) for 5 hours. They accumulated approximately $2.0 \mathrm{ppm}$ total naphthalenes in their tissues and had respiratory rates which were depressed to a level similar to that of animals which had been starved for 48 hours. Seven days after exposure, the shrimp had released the naphthalenes during maintenance and feeding in clean water and their respiratory rates had returned to the control level.

At the University of Texas the investigators have been studying the effects of the water soluble components of petroleum oils and derivatives on marine animals. A series of fuel oils, petroleum cuts. fractions of No. 2 fuel oil and automotive oils have been examined. The main emphasis has been on the aromatic components of the water soluble fraction, and selected aromatics found therein have been tested individually. In these investigations both adult and early developnental stages have been studied. It was expected that aquatic animals, during the several stages of their life histories, would possess variable resis- 
tance to petroleum toxicosis. It was desirable to evaluate the harmful effects of both chronic, sublethal levels of such toxicants on population maintenance, and the more dramatic acute effects of short lethal exposures. Eggs and larvae, especially those having a planktonic phase, may be the stages in the life histories that are especially susceptible to petroleum poisoning: or adversely affected by petroleums at levels below those demonstrably affecting the adults.

To determine the effects of petroleum oils on young stages of marine animals, echinoderm and crustacean larvae have been used by the University of Texas group at Port Aransas. Echinoderm eggs are especially suitable for observing deviations from normal development because of the ease with which they can be collected, the large body of enubryological knowledge available concerning them, and their demonstrated sensitivity to slight changes in the environmental media. Experiments were successfully carried out on the effects of fuel oil on the activity of gametes and the early development of sand dollar eggs. Sperm activity, respiration, fertilization, cleavage and early development to the pluteus stage were monitored. At a level of $0.6 \mathrm{ppm}$ of WSF of the API fuel oil, sperm motility ceased, fertilization was hampered and abnormalities of cleavage became observable; at higher concentrations, there was much mortality and gross retardation of larval developmeni. On the other hand, a crude oil-Kuwait-at even high concentration, had little effect on development.

Crustaceans studied were barnacles (eggs and nauplii) and crabs (zoeae and megalops). Development of barnacle eggs was adversely affected by No. 2 fuel oil (WSF) at concentrations of $0.3 \mathrm{ppm}$ and greater, especially in early stages. Older embryos were more tolerant; hatching was slightly accelerated, but the larvae on emerging were quickly killed. During short exposures it appears that the egg shell affords some protection to the embryo.

Considerable differences were discovered in the toxic effects of the several oils investigated. Such differences are not unexpected because of gross differences in composition of the oils. In order to evaluate the relative toxicities of petroleum oils, short experiments of 1 and 24h were carried out with barnacle larvae. An automated method was used to count the larvae, live or dead, after exposure, and curves of effect $v s$ concentrations of water solubles of six oils, fractions of fuel oil and thirteen aromatics were obtained (Fig. 4). Crude oils were toxic in the order Venezuela $>$ Kuwait $>$ Alaska $>$ Southern Louisiana. Of oil derivatives, used crankcase oil was by far the most toxic (Table 10). Some especially toxic aromatics were 1-methyl naphthalene, dimethyl 


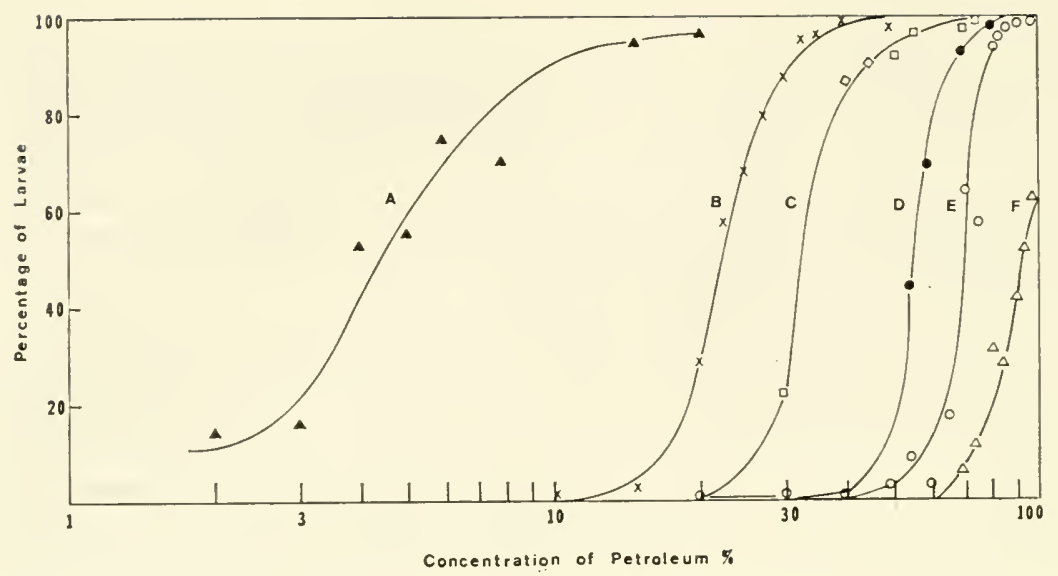

Figure 4. Effects of petroleum oils on activity of barnacle nauplii. Ordinate, percentage of larvae in the bottom fraction of the experimental tube; abscissa, concentration of oil-stock (water soluble fraction). Curves A, Crankcase motor oil. B, No. 2 Fuel oil (API): C, Bunker C; D. Venezuelan crude; E, Alaskan crude: F. Southem Louisiana crude.

naphthalene, naphthalene, indan, 1,2,4-trimethyl benzene, and 1,3,5trimethyl benzene.

Larvae of crabs (hermit, spider and stone) were equally sensitive to No. 2 fuel oil, which was deleterious to development and survival. The most striking effects were found with stone crab zoeae, the mortality increasing with the concentration (Fig. 5). In addition to survival, significant differences from controls were observed in the condition of the larvae and the rate of development. Higher concentrations of oil retarded growth and inhibited molting of hermit and spider crab larvae, the effects appearing at a concentration of $0.5 \mathrm{ppm}$.

Larvae of benthic animals during their planktonic existence have stereotyped activity patterns which lead them to suitable positions for feeding and dispersal; later, when they approach metamorphosis, behavioral responses enable them to choose suitable places to settle. Interference with normal activity places larvae in jeopardy; for example, barnacle larvae (nauplii) are attracted to light and swim upwards in the water column; petroleum oils at low levels abolish this response and, therefore, interfere with the animals' normal mechanism of dispersion.

Most of the Texas experiments have been carried out with coastal and inshore species, which are more readily available, but the investigations are being extended to offshore pelagic species. An example 
Effect of Petroleum on Nauplii of Balanus amphitrite niveus (1 hour experiments).

\begin{tabular}{lcrrr}
\hline \multicolumn{1}{c}{ Petroleum Oil } & $\begin{array}{c}\text { Concentration } \\
\text { for } \mathrm{D}_{\tilde{5}}^{\mathbf{1 h}}\end{array}$ & A & B & C \\
\hline Southern Louisiana crude (API) & 93 & 100 & \\
Alaskan crude & 70 & 100 & & \\
Kuwait crude (API) & 68 & 50 & 100 & \\
Venezuelan crude & 56 & 100 & & \\
Diesel fuel oil (UT) & 62 & 100 & & \\
No. 2 fuel oil (API) & 22 & 10 & 20 & 50 \\
Crankcase oil (Havoline) & 4.5 & 4 & 5 & 40 \\
Used crankcase oil & 3 & 5 & 15 & 50 \\
\hline
\end{tabular}

Explanation. $\mathrm{D}_{50}^{\text {lh }}$ Concentration (as percentage of oil stock solution) at which half the larvae were present in the bottom of the experimental tube after lh.

${ }^{1}$ Behavior of larvae in the bottom fraction. Approximate threshold concentrations for, A, all larvae swimming; $B$, barely swimming or few swimming; C, mostly dead.

is a study of the pelagic pteropod Creseis acicula, of which large numbers were used to test the toxic effects of No. 2 fuel oil Exxon (Baytown). Concentrations of $0.4 \mathrm{ppm}$ and more were toxic, reducing survival; mortalities increased at higher concentrations and with duration of exposure (Figs. 6 and 7). At concentrations of $0.2 \mathrm{ppm}$, pteropods retracted and ceased to swim; at lower concentrations, swimming activity continued normally, at least for the first $24 \mathrm{~h}$.

The chemical senses are very important in the feeding and activities of fishes, such as orientation, species recognition, etc. With a view to exploring damping of chemical senses by petroleum, sea catfishes (Arius felis) were exposed to fuel oil for several days. Overt activity was watched and electrocardiograms were recorded, since slight changes in environmental conditions have been found to be reflected in changes of cardiac activity. It was found that low concentrations of petroleum oils, $0.2 \mathrm{ppm}$, caused a temporary slowing of heart beat, fish made exploratory efforts to escape from their containers. During prolonged exposure fish succumbed, but feeding among the survivors was not interrupted. However, the fish were unable to retain their food, and their gills and fins became seriously damaged.

The experiments with animals have shown that the various crude oils and petroleum derivatives differ greatly in toxicity. Southern 


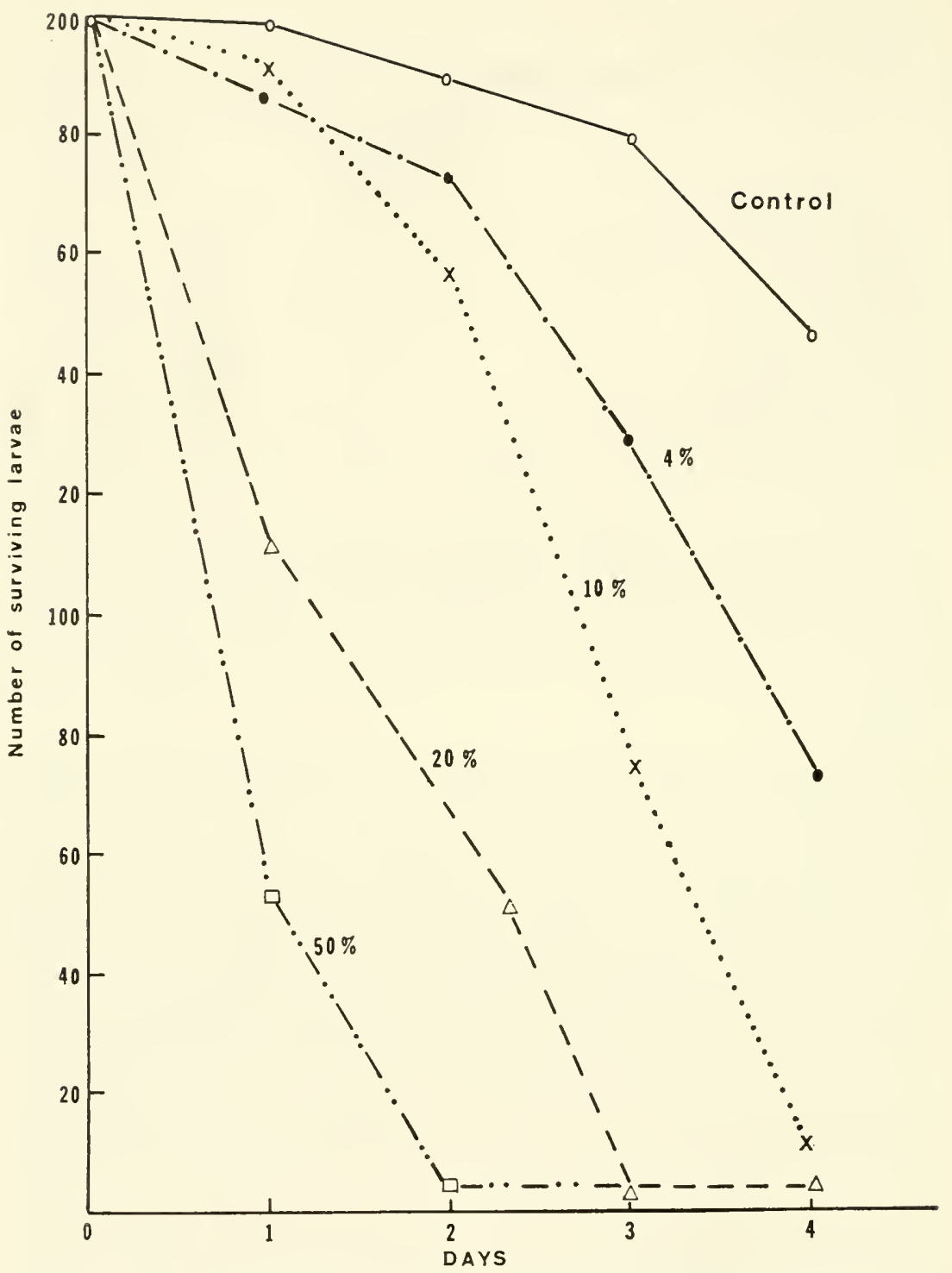

Figure 5. Survival (by days) of stone crab larvae in petroleum oil solutions, compared with a control. The number on the curves refer to dilutions of oil-stock solution (No. 2 fuel oil, API).

Louisiana crude is relatively non-toxic, Venezuelan crude more so, whereas No. 2 fuel oil and automotive oils are very toxic. Levels at which toxicities appear in acute experiments with No. 2 fuel are about 0.2 to $0.7 \mathrm{ppm}$. Toxicity increases with concentration and duration of 


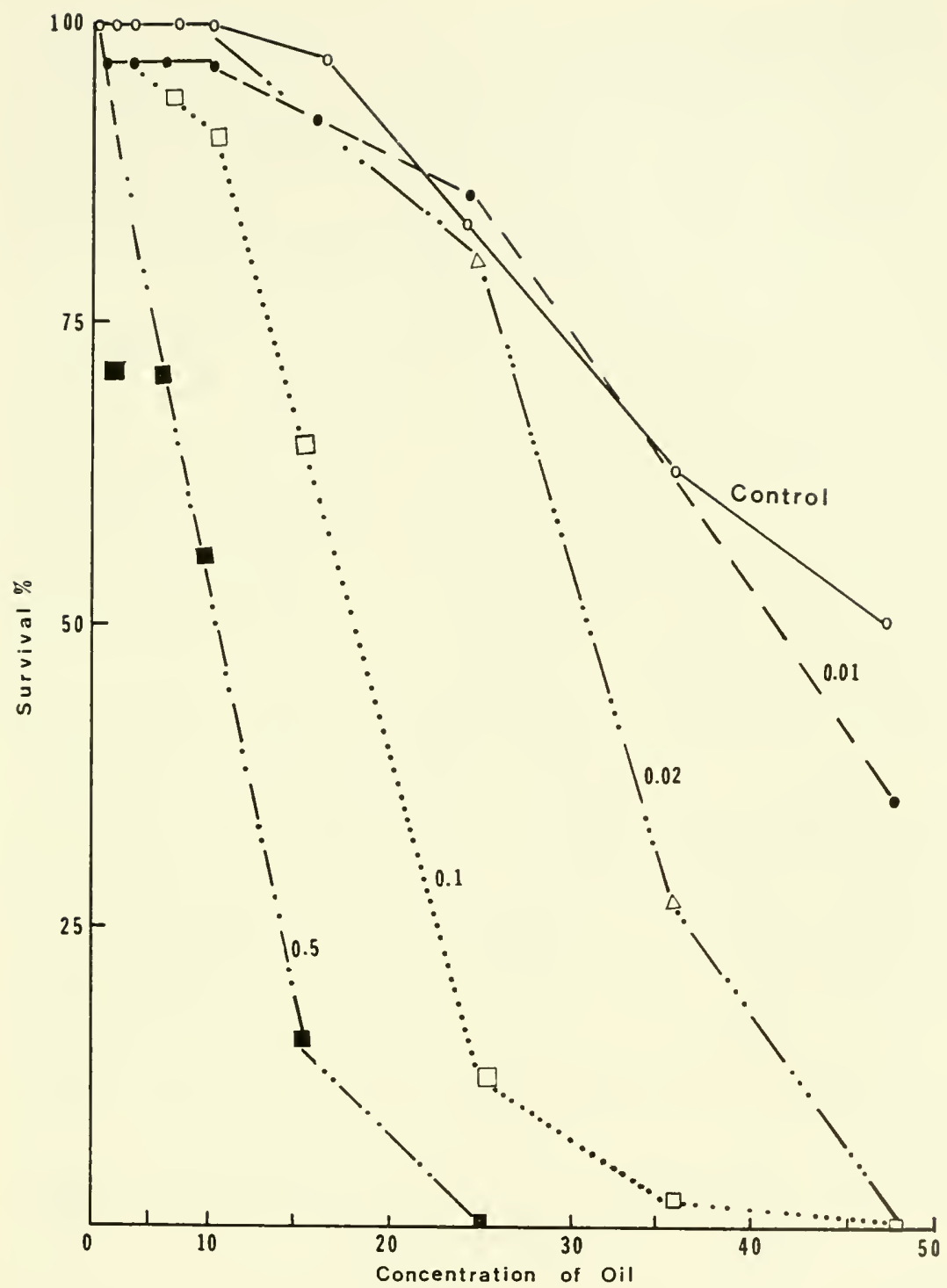

Figure 6. Mean survival times of an oceanic pteropod mollusc Creseis acicula in various concentrations of water soluble and reaction of No. 2 flel oil (Exxon Baytown).

exposure. It is demonstrable that many of the aromatic compounds occurring in petroleum oils are harmful to marine animals, and relative toxicities of some of them have been determined. Here, however, 


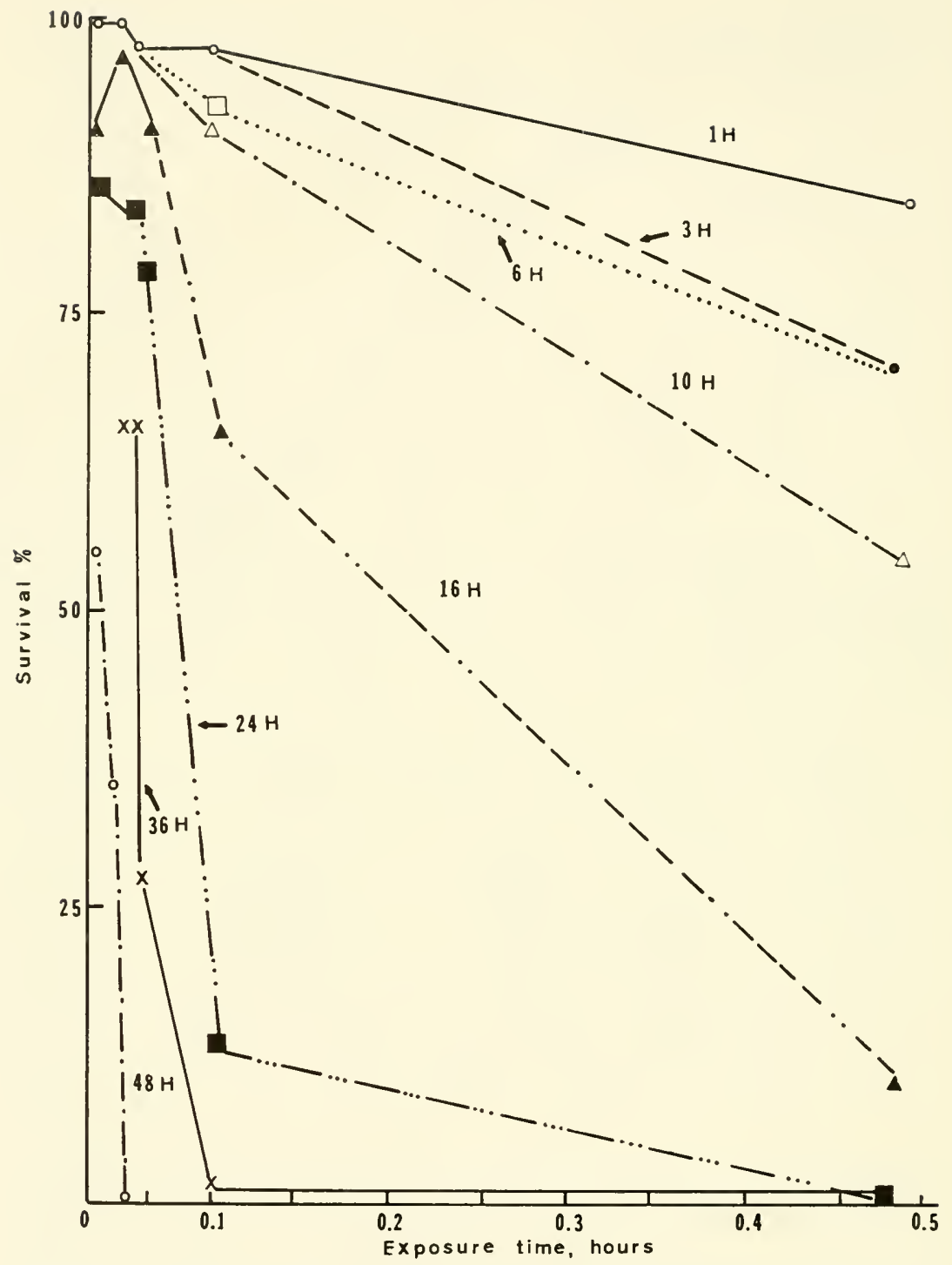

Figure 7. Mean survival of Creseis acicula vs concentrations of water soluble fractions of No. 2 fuel oil for various exposure times. Compare Figure 6.

data are limited, restricted as they are to one species, whereas it is to be expected that species differences will exist in this regard.

\section{Trace Metals}

The biological effect of heavy metals was studied by the Texas A\&M 
group using the same animals and techniques similar to those used in petroleum experiments. Chlorine ion regulation was studied as a physiological indicator of mercury pollution. Although ninety-six hour $\mathrm{LC}_{50}$ values ranged from 50 to 64 part per billion of mercury for the porcelain crab (Petrolisthes armatus) this exposure did not alter chlorine ion regulation (Roesijadi et al., 1974). Likewise blood chloride ion regulation of the grass shrimp (Palaemonetes pugio) was unaffected by exposure of the animals to $50 \mathrm{ppb}$ of cadmium.

During a cruise in the Gulf of Mexico aboard Texas A\&M's R/V Gyre penaeid shrimp, Penaeus aztecus, were collected and tested for accumulation of mercury $(\mathrm{Hg})$ and the effects of $\mathrm{Hg}$ exposure on chloride ion regulation. Control animals contained $4.6 \mathrm{ppb} \mathrm{Hg}$, which was distributed as $64 \%$ in the "meats" and $36 \%$ in the "shell" or exoskeleton. After exposure to $500 \mathrm{ppb} \mathrm{Hg}$ for 2 hours, shrimp contained a mean level of $285 \mathrm{ppb}$ of which $91 \%$ was associated with the exoskeleton. While this short-term exposure to a high level of $\mathrm{Hg}$ resulted in most of the metal being absorbed to the exoskeleton, longterm low level exposures produce higher concentrations in the internal organs and tissues. Shrimp exposed to $500 \mathrm{ppb}$ and transferred from environmental salinity $(28 \%$ ) to $14 \%$ were less able to adjust internal chloride ion concentrations than control animals.

Studies with mercury and postlarvae of the white shrimp, Penaeus setiferus, were also conducted at Texas A\&M. Toxicity studies with $\mathrm{Hg}$ showed that two different size classes (7-13 $\mathrm{mm}$ and $15-25 \mathrm{~mm}$ ) exhibited approximately the same 96 hour $\mathrm{LC}_{50}$ value $(17-20 \mathrm{ppb})$. Even after a 60 day period of pre-exposure to $1 \mathrm{ppb}$, the 96 hour $\mathrm{LC}_{50}$ remained essentially unchanged. Other measurements taken after the 60 day period of exposure to either 0.5 or $1.0 \mathrm{ppb}$ of $\mathrm{Hg}$ failed to demonstrate any sublethal effect of these long-term exposures. Respiratory rate of postlarvae, as well as growth and molting rate were not significantly affected by 60 days exposure to either 0.5 or $1.0 \mathrm{ppb}$ of $\mathrm{Hg}$. It is again interesting to note that no sublethal effects are exhibited at $1 \mathrm{ppb}$, while the 96 hour $\mathrm{LC}_{50}$ value for these postlarvae is a little over one order of magnitude higher (17-20 ppb Hg).

\section{Polychlorinated Biphenyls (PCBs)}

The Texas A\&M group studied the biological effects of PCBs making use of procedures developed in petroleum and trace metal work. Chemical analyses of the exposure media were conducted during these experiments and it was found that concentrations of Aroclor 1254 in exposure media decreased with time, dropping to $20 \%$ of initial values 
in 96 hours. The decrease of Aroclor 1254 can probably be attributed to volatilization and, to a lesser extent, by uptake of organisms and absorption to the glass walls of exposure containers. Such phenomena create difficulties in toxicity analysis since organisms are not exposed to a constant level of toxicant throughout the experiment. The initial exposure concentration has been used in expressing the toxicity of Aroclor 1254 to Palaemonetes pugio. Although such a practice does not completely describe the experimental situation, relative toxicities to organisms under similar conditions would not be altered. In the larval experiment, concentrations fluctuated in 2-day cycles since exposure media were renewed every second day.

Ninety-six hour $\mathrm{LC}_{50}$ values for adult shrimp are presented in Table $11 \mathrm{~A}$. Since the presence of $200 \mathrm{mg} /$ liter acetone did not decrease the $96 \mathrm{~h}$ LC $_{50}$ of the "partially equilibrated" seawater, it was concluded that synergism by acetone and Aroclor 1254 did not occur. The slightly lower $96 \mathrm{~h} \mathrm{LC}_{50}$ of $41 \mathrm{ug} /$ liter for shrimp exposed to Aroclor 1254 dissolved in acetone may have resulted from the PCBs occurring in a more finely dispersed state due to the activity of the solvent carrier.

Juvenile shrimp with $96 \mathrm{~h} \mathrm{LC}_{50}$ values from 6.1 to $7.8 \mathrm{ug} / \mathrm{liter}$ (Table 11) were more sensitive than adults. Values were slightly lower at the lower salinities, but the magnitude of the difference was

TABLE 11

Toxicity of Aroclor 1254 to Adult and Juvenile Palaemonetes pugio: $96 \mathrm{~h} \mathrm{LC}_{50}$ Values.

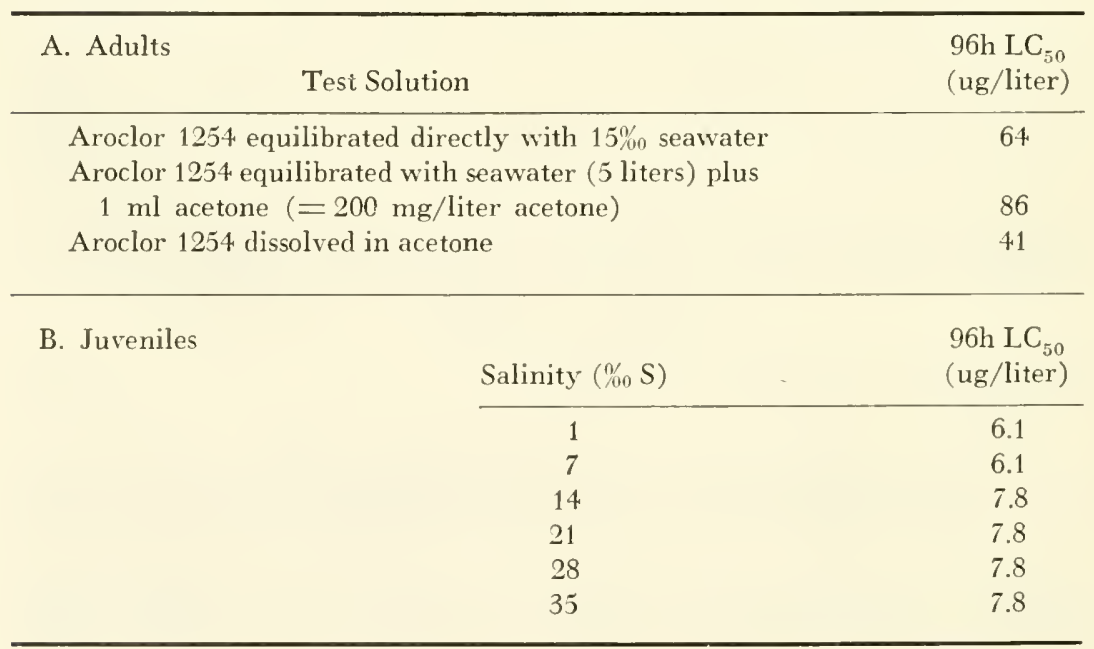


so small that no effect of salinity on Aroclor 1254 toxicity was apparent.

Development of $P$. pugio to postlarvae occurred at exposure concentrations below $15.6 \mathrm{ug} /$ liter (Table 12). At $15.6 \mathrm{ug} / \mathrm{liter}, 75 \%$ of the larvae died on the fifth and sixth days of exposure and all died within 11 days. At concentrations of 3.2 and $<0.1 \mathrm{ug} /$ liter, percent survival to the postlarval stage did not differ from that of controls. However, the duration of development to postlarvae increased as the concentration increased from 0 to $3.2 \mathrm{ug} /$ liter. Controls averaged 22.7 days to postlarvae. Mean larval duration for groups exposed to $0.1 \mathrm{ug} / \mathrm{liter}$ was 24.0 days, and those exposed to $3.2 \mathrm{ug} /$ liter was 26.4 days. Differences among means were statistically significant at $\mathrm{p} 0.10$.

\section{Phthalate Esters}

Since DEHP is the most prevalent of the phthalate esters, initial $96 \mathrm{~h} \mathrm{LC}_{50}$ determinations were performed with it. In assays performed with the grass shrimp, Paleomonetes pugio, and with 3 species of fish, Cyprinodon variegatus, Menidia beryllina and Fundulus similis, no toxicities were observed up to the highest level tested normally. Toxicity studies with two lower molecular weight phthalates, dimethyl (DMP) and dibutyl (DBP) phthalates, have also been performed with the grass shrimp. The $96 \mathrm{~h} \mathrm{LC}_{50}$ s determined for those compounds were 7 ppm for DMP and 6 ppm for DBP.

\section{TABLE 12}

Toxicity of Aroclor 1254 to Larval Palaemonetes pugio: Survival and Duration of Larval Development.

\begin{tabular}{cccc}
\hline $\begin{array}{c}\text { Aroclor 1254 concentration } \\
\text { (ug/liter) }\end{array}$ & $\begin{array}{c}\text { Number of } \\
\text { larvae }\end{array}$ & $\begin{array}{c}\text { Percent } \\
\text { survival }\end{array}$ & $\begin{array}{c}\text { Days to } \\
\text { postlarvae }\end{array}$ \\
\hline 0 (acetone control) & 30 & 93 & $22.7 \pm 1.6$ \\
$<0.1$ & 30 & 100 & $24.0 \pm 2.6$ \\
3.2 & 30 & 90 & $26.4 \pm 3.8$ \\
15.6 & 30 & 0 & $-\mathrm{a}$ \\
\hline
\end{tabular}

-a. $75 \%$ died on the 5 th and 6 th days of exposure at $15.6 \mathrm{ug} / \mathrm{liter}$. No larvae survived longer than day 11 . 


\section{Conclusion}

The complexity of assessing the impact of pollutants on the marine biota was recognized by all of the program scientists. It was agreed that significant cases of lethal and sublethal biological effects had been observed. The problem of using this knowledge to evaluate environmental impacts for real ecosystems was known to all the participants. Nevertheless it is generally concluded that at some point many small cases of damage to organisms will result in significant damage to the marine ecosystem. Because we are not yet able to say how many small events add up to a major one it was urged that care be taken to protect the environment from toxic substances. 


\section{References}

Allen, H., "Effects of petroleum fractions on the early development of a sea urchin," Marine Pollution Bull. 2, 138-140 (1971).

Anderson, J. W., J. M. Neff, B. A. Cox, H. E. Tatem, and G. M. Hightower, "Characteristics of dispersions and water-soluble extracts of crude and refined oil and their toxicity to estuarine crustaceans and fish," Marine Biology, 27, 75-88 (1974).

Baseline Studies of Pollutants in the Marine Environment and Research Recommendations, IDOE Baseline Conference, Brookhaven, New York, May 24-26, 1972, 12 p. (1972).

Eganhouse, R. P. and J. A. Calder, "The solubility of medium molecular weight aromatic hydrocarbons and the effects of hydrocarbon co-solutes and salinity," submitted (1975).

Giam, C. S., H. S. Chan, and G. S. Neff, "A sensitive method for the determination of phthalate ester plasticizers in open ocean biota samples," Anal. Chem., 47, 2225-2228 (1975).

Iliffe, T. M. and J. A. Calder, "Dissolved hydrocarbons in the eastern Gulf of Mexico loop current and the Caribbean Sea," Deep-Sea Research, 21, 481-488 (1974).

Kuhnhold, W. W., "The influence of water soluble compounds of crude oils and their fractions on the ontogenetic development of herring fry (Clupea harrengus)," Berdt Wiss. Komman. Merresforsch., 20, 165-171 (1969).

Marine Pollution Monitoring, the NOAA Marine Pollution Monitoring Conference, Santa Catalina Marine Biological Laboratory, October 25-28, 1972.

NAS, National Academy of Sciences, Marine Environmental Quality, Workshop Report. August 9-13, 1971.

Pollutant Transfer to the Marine Environment, the IDOE Pollutant Transfer to the Marine Environment Conference, Port Aransas, Texas, January 11-12, 1974.

Pulich, W., K. Winters, and C. Van Baalen, "The effects of a No. 2 fuel oil and two crude oils on the growth and photosynthesis of microalgae," Marine Biology, 28, 87-94 (1974).

Roesijadi, G., S. R. Petrocelli, J. W. Anderson, B. J. Presley, and R. Sims, "Survival and chloride ion regulation of the porcelain crab Petrolisthes armatus exposed to mercury," Marine Biology, 27, 213-217 (1974).

Sutton, C. and J. A. Calder, "Solubility of higher-molecular-weight n-paraffins in distilled water and seawater," Environmental Science and Technology, 8, 654 657 (1974).

Sutton. C. and J. A. Calder, "Solubility of alkylbenzenes in distilled water and seawater at $25.0^{\circ} \mathrm{C}, " J$. Chemical and Engineering Data, in press (1975). 


\section{Appendices}

\section{Appendix 1: NSF/IDOE Effects of Pollutants on Marine Organisms Program Executive Committee}

The group at the Sidney Workshop recognized that the NSF/IDOE Effects Program needed an additional level of scientific management. The Program has consisted of individuals with separate research grants working toward the program goal with informal contact with each other, but under the overall management of IDOE. It is proposed to organize the scientists into a formal management unit following the same pattern that the NSF/IDOE Pollutant Transfer Program has used.

Toward this end the participants in the Workshop recommended that Program Executive Committee be set up. The structure and function of the Executive Committee would be:

1. To provide scientific guidance to the NSF/IDOE Office with respect to the Effects of Pollutants on Marine Organisms Program, with particular attention to the development of comprehensive long-range plans for accomplishing the objectives of this program and the identification of weaknesses as they develop in the existing program.

2. To initiate and coordinate intercalibration, sample exchange, and jcint experiments among the Effects Program participants.

3. To organize summer institutes, special workshops, the production of special standards and other similar cooperative efforts to further the goals of the Effects Program.

4. To cooperate with the NSF/IDOE Environmental Quality Program Manager in the preparation and presentation of the various required reports of the Program to the National Science Foundation.

5. To simulate and solicit strong research proposals relevant to the long-range plan and goals of the Program and to comment on the applicability of submitted proposals to the long-range plan and goals.

6. To establish panels to assist in the development of programs in any particular areas of need, such as culture techniques, intercalibration, sampling techniques, data processing, physiological parameters, etc.

7. To establish an effective system of communication of scientific results among Program participants, the scientific community in general. and the public. 
It is further recommended that the Executive Committee be composed of three people actively involved in the IDOE Effects of Pollutants on Marine Organisms Program and one person, appointed by the IDOE office, actively involved in similar research but not a part of this program. The three members from the Program should be elected by the principal investigators of active grants. All members should be appointed for two-year terms, except two of the initial four members should be appointed to three-year terms. The Program Manager for Environmental Quality at IDOE and his immediate predecessor should be ex-officio members of the Executive Committee. One member of the Committee should be elected Chairman by the Committee members.

The Executive Committee should have an administrative system to provide travel, communication, secretarial assistance, etc., for various functions outlined above. The administrative function should be located with the Chairman of the Executive Committee. It should be recognized that this is an internal committee and does not serve to provide IDOE with external advice.

\section{Áppendix 2: IDOE Projects for Effects of Pollutants on Marine Or- ganisms Program}

\section{Organization}

Florida State University

Department of Oceanography

Oregon State University

Department of Oceanography

Texas A\&M University

Department of Oceanography

Department of Biology

Texas A\&M University

Department of Oceanography

Department of Biology

Texas A\&M University

Department of Chemistry

University of Texas at Austin Marine Science Laboratory
Investigator

J. A. Calder

R. L. Holton*

W. M. Sackett

J. Anderson

B. J. Presley*

S. R. Petrocelli*

C. S. Giam

J. A. C. Nicol

C. Van Baalen
Project Title

Investigations of the Breakdown and Sublethal Biological Effects of Trace Petroleum Constituents in the Marine Environment

The Effect of Polychlorinated Biphenyls on Marine Organisms

Fate, Spatial and Temporal Distribution of PetroleumDerived Organic Compounds in the Ocean, and Their Sublethal Effects on Marine Organisms

Sublethal Effects of Heavy

Metals on Organisms from the Gulf of Mexico

Isolation, Characterization, Quantitation, and Biological Effects of Phthalates and Chlorinated Hydrocarbons in Biota from the Gulf of Mexico

Marine Petroleum Pollution:

Biological Effects and

Chemical Characterization 
University of Texas,

Galveston Medical Branch

Texas A\&M University

Department of Biology

University of California

Scripps Institution of

Oceanography

University of Georgia System R. F. Lee

Skidway Institution of

Oceanography

* No longer participating in the program
J. W. Anderson

J. M. Neff
Physiological Effects of Water Soluble Hydrocarbons on Marine Invertebrates

Sub-lethal effects of selected heavy metals and organic compounds on organisms from the Gulf of Mexico

Assimilation of lead, cadmium and thallium by marine organisms with consideration of biological effects

Fate of petroleum hydrocarbons in the marine food web

\section{Appendix 3: Publications Resulting from the NSF/IDOE Effects of pollutants on Marine Organisms Program}

Anderson, J. W., R. C. Clark, and J. J. Stegeman, "Contamination of marine organisms by petroleum hydrocarbons," pp. 36-75. In Marine Bioassays Workshop Proceedings, Sponsored by A.P.I.E.P.A. and Marine Technology Soc. 308 pp. (1974).

Anderson. J. IV.. J. M. Neff, and S. R. Petrocelli, "Sublethal effects of oil, heavy metals and PCBs on marine organisms," pp. 83-121. In Survival in Toxic Environments, M.A.Q. Khan and J. P. Bederka. Jr., eds. Academic Press, N.Y., 553 pp. (1974).

Anderson, J. W., J. M. Neff, B. A. Cox, H. E. Tatem, and G. M. Hightower, "The effects of oil an estuarine animals: Toxicity, uptake and depuration, respiration," pp. 285-310. In Pollution and Physiology of Marine Organisms, F. J. and W. B. Vernberg, eds., Academic Press, N.Y., 492 pp. (1974).

Brooks, J. M., A. D. Fredericks, and W. M. Sackett, "Baseline concentrations of light hydrocarbons in Gulf of Mexico," Env. Sci. \& Tech. 7, 639-642 (1973).

Brooks, J. M. and W. M. Sackett, "Sinks and concentrations of light hydrocarbons in the Gulf of Mexico," J. Geophys. Res. 78, 5248-5258 (1973).

Brooks, J. M., J. R. Gormly, and W. M. Sackett, "Molecular and isotopic composition of two seep gases from the Gulf of Mexico," Geophys. Res. Lett. 1, 213-216 (1974).

Brooks, J. M. and W. M. Sackett, "Significance of low-molecular-weight hydrocarbons in marine waters," 7th International Meeting on Organic Geochemistry, in press (1975).

Cox, B. A., J. W. Anderson, and J. C. Parker, "An experimental oil spill: The distribution of aromatic hydrocarbons in the water, sediment, and animal tissues within a shrimp pond, pp. 607-612. In Proceedings of Conference on Prevention of Oil Pollution, Sponsored by A.P.I. E.P.A. and U.S.C.G., 612 pp. (1975).

Eganhouse, R. P. and J. A. Calder, "The solubility of medium molecular weight aromatic hydrocarbons and the effects of hydrocarbon co-solutes and salinity. Submitted. 
Gormly, J. R. and W. M. Sackett, "Anthropogenic alteration of sedimentary organic carbon." Geophys. Res. Lett. 2, 197-200 (1975).

Gormly. J. R. and IV. M. Sackett, "Carbon isotope evidence for the maturation of marine lipids," 7 th International Meeting on Organic Geochemistry, in press (1975).

Neff, J. M. and J. W. Anderson, "Accumulation, release and distribution of benzo [a]pyrene-C14 in the clam Rangia cuneata," pp. 469-471. In Proceedings of Conference on Prevention of Oil Pollution, Sponsored by A.P.I. E.P.A. and U.S.C.G., 612 pp. (1975).

Neff, J. M. and J. W. Anderson, "Ultraviolet spectrophotometric method for the determination of naphthalene and alkylnaphthalenes, in the tissues of oilcontaminated marine animals," Bull. Env. Contam. and Toxicol., in press (1975).

Pulich. W., K. Winters, and C. Van Baalen, "The effects of a No. 2 fuel oil and two crude oils on the growth and photosynthesis of microalgae," Marine Biology, 28, 87-94 (1974).

Roesijadi, G., S. R. Petrocelli, J. W. Anderson, B. J. Presley, and R. Sims, "Survival and chloride ion regulation of the porcelain crab Petrolisthes armatus exposed to mercury," Marine Biology 27, 213-215 (1974).

Roesijadi, G., S. R. Petrocelli, J. W. Anderson, C. S. Giam, and G. E. Neff, "Toxicity of polychlorinated biphenyls (Aroclor 1254) to adult, juvenile and larval stages of the shrimp Palaemonetes pugio," Submitted to Bull. Environ. Contam. Toxicol. (1975).

Sackett. W. M., "Significance of low molecular weight hydrocarbons in eastern Gulf waters," In Symposium on Marine Environmental Implications of Offshore Drilling in the Eastern Gulf of Mexico, State University System of Florida (1974).

Sackett, IV. M. and J. M. Brooks, "Origin and distributions of low-molecular-weight hy-drocarbons in the Gulf of Mexico coastal waters," ACS Symposium on Marine Chemistry in the Coastal Environment in Philadelphia, April 8-10, 1975, in press (1975).

Sutton. C. and J. A. Calder, "Solubility of alkylbenzenes in distilled water and seawater at $25.0^{\circ}$ C.." J. Chemical and Engineering Data, in press (1975).

Winters, K., R. O'Donnell, J. Batterton, and C. Van Baalen, "Water soluble components of four fuel oils: chemical characterization and effects on growth of microalgae," Marine Biology, in press (1975).

\section{Appendix 4: NSF/IDOE Effects of Pollutants on Marine Organisms Program Workshop Participants, Sidney, B.C., Canada, August 11-14, 1974}

Jack W. Anderson

Department of Biology

Texas A\&M University

College Station, Texas 77843

John Calder

Department of Oceanography

Florida State University

Tallahassee, Florida 32306
Robert A. Duce

Graduate School of Oceanography

University of Rhode Island

Kingston, Rhode Island 02881

C. S. Giam

Department of Chemistry

Texas A\&M University

College Station, Texas 77843 
Ed Goldberg

Scripps Institution of Oceanography

University of California

La Jolla, California 92037

Deane E. Holt

Program Manager

Living Resources, IDOE

National Science Foundation

Washington, D. C. 20550

Robert Holton

School of Oceanography

Oregon State University

Corvallis, Oregon 97331

Feenan Jennings

Office of the International

Decade of Ocean Exploration

National Science Foundation

Washington, D. C. 20550

James S. Kittredge

Marine Biomedical Lab

University of Texas Medical School

Galveston, Texas 77550

Richard Lee

Skidaway Institute of Oceanography

Savannah, Georgia 31406

Paul Lefcourt

Office of Research \& Development

Environmental Protection Agency

Washington, D. C.

David IV. Menzel

Skidaway Institute of Oceanography

Savannah, Georgia 31406

Grace S. Neff

Department of Chemistry

Texas A\&M University

College Station, Texas 77843

Jerry M. Neff

Department of Biology

Texas A\&M University

College Station, Texas 77843

J. A. Colin Nicol

The University of Texas

Marine Science Laboratory

Port Aransas. Texas 78373

Patrick L. Parker

The University of Texas
Marine Science Laboratory

Port Aransas, Texas 78373

Tim Parsons

Institute of Oceanography

University of British Columbia

Vancouver, B. C., Canada

Sam R. Petrocelli

Department of Biology

Texas A\&M University

College Station. Texas 77843

Bob J. Presley

Program Associate

for Environmental Quality, IDOE

National Science Foundaiton

Washington, D. C. 20550

William Sackett

Department of Oceanography

Texas A\&M University

College Station, Texas 77843

John Steele

Marine Laboratory

Aberdeen, Scotland

United Kingdom

IVilliam H. Thomas

Scripps Institution of Oceanography

University of California

La Jolla, California 92037

C. Van Baalen

The University of Texas

Marine Science Laboratory

Port Aransas, Texas 78373

Kenneth Winters

The University of Texas

Marine Science Laboratory

Port Aransas, Texas 78373

Bernt Zeitzschel

Institut fur Meereskunde an der

Universitat Kiel

$23 \mathrm{Kiel}$

Dusternbrooke Weg 20

Germany

V. Zitko

Department of Environment

Biological Station

St. Andrews, N.B., Canada 




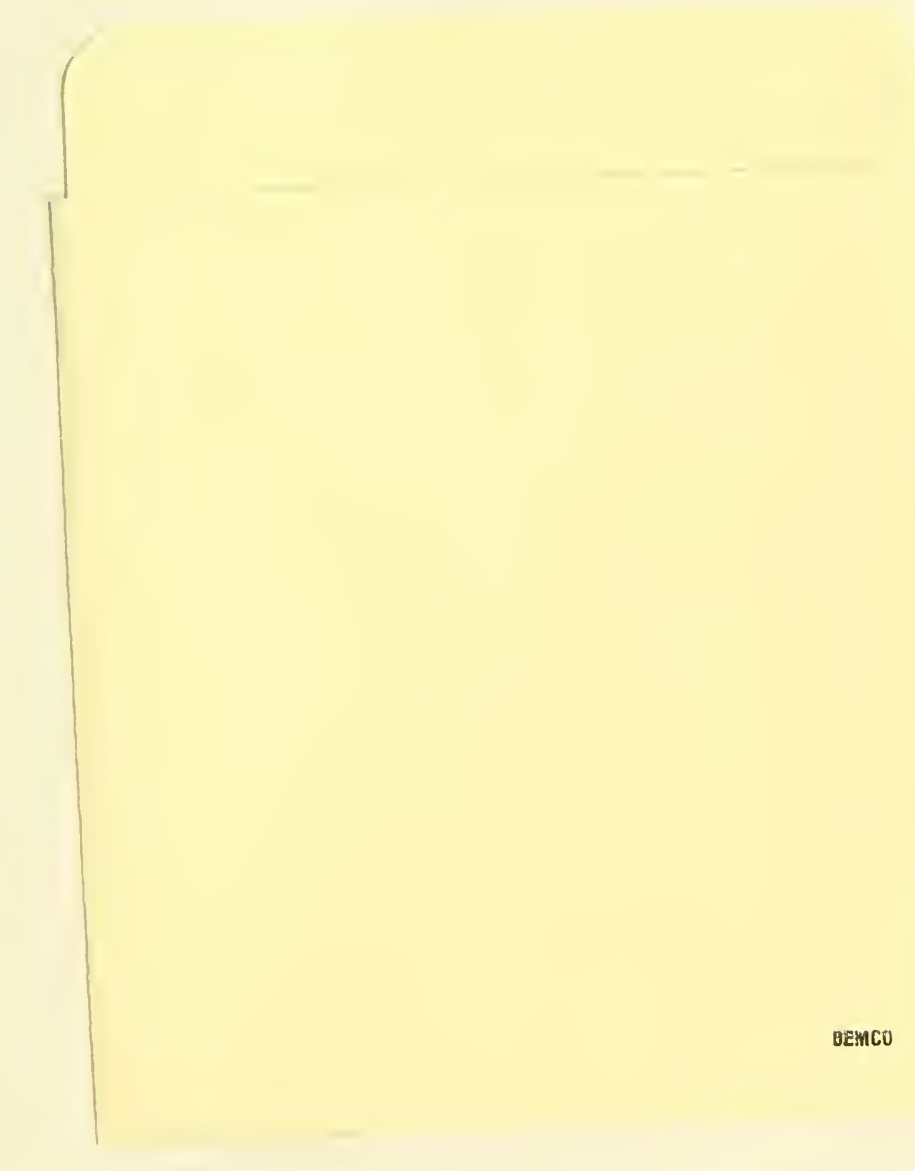




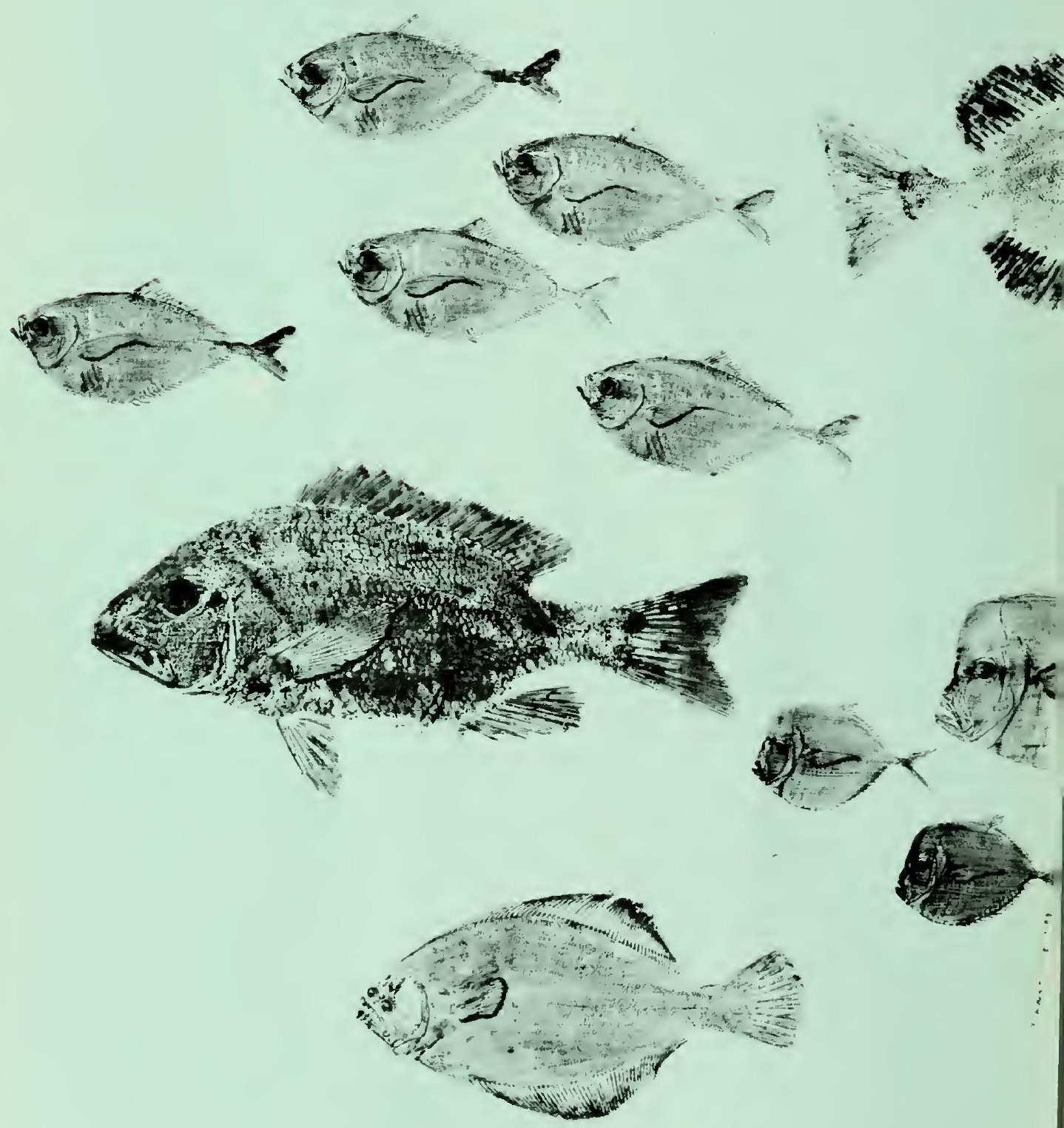

